\title{
Seismic disasters and the demographic perspective: 1968, Belice and 1980, Irpinia-Basilicata (southern Italy) case studies
}

\author{
Maddalena De Lucia $*, 1$, Federico Benassi ${ }^{2}$, Fabrizio Meroni ${ }^{3}$, \\ Gemma Musacchio ${ }^{4}$, Nicola Alessandro Pino ${ }^{1}$, Salvatore Strozza ${ }^{5}$ \\ (1) Istituto Nazionale di Geofisica e Vulcanologia, Osservatorio Vesuviano, Napoli, Italy \\ (2) Italian National Institute of Statistics (Istat), Roma, Italy \\ (3) Istituto Nazionale di Geofisica e Vulcanologia, Sezione di Milano, Milano, Italy \\ (4) Istituto Nazionale di Geofisica e Vulcanologia, Amministrazione Centrale, Roma, Italy \\ (5) University of Naples Federico II, Department of Political Sciences, Napoli, Italy
}

Article history: received July 4, 2019; accepted December 9, 2019

\begin{abstract}
One of the challenges on disasters' understanding is the assessment of impact from a more global perspective, adding to their scenario of injuries, deaths, homeless and economic losses, those effects that are mostly widespread and could last for a long period of time, driving to a serious disruption of a community or a society. Seismic disasters are not just the results of the energy released by the earthquake or buildings' vulnerability: social, demographic, cultural parameters may instead play a crucial, yet underestimated, role. We carried out a pilot study to investigate the demographic perspective of the impact of 1968 Belice and 1980 Irpinia-Basilicata earthquakes on local communities. The macroseismic MCS intensities were used as a primary parameter upon which the demographic scenario was derived. Population annual growth rates, the ageing index, the childwoman ratio, and the Gini index from the demographic data census of the period 1951-2011 were analyzed to assess population dynamics, age structure evolution and its level of spatial concentration within the disasters' areas. Demographic data were then matched to macroseismic intensities to outline a new, original analysis which describes the impact of the two seismic disasters with a broad multi-parameter perspective. The results highlight also the existence of a general marginality of most affected areas with respect to the processes of population growth, ageing and fertility, as well as for distribution of the regional population, occurring already before the disasters stroke. This marginality might have enhanced the impact of disasters by significantly increasing vulnerability.
\end{abstract}

Keywords: Belice earthquake; Irpinia-Basilicata earthquake; Demography.

\section{Introduction}

Disasters reveal the negative impact of hazards, overwhelming the capacity of a community to cope [Twigg, 2001]. Mostly known for deaths, injuries and property tolls, disasters also cause disruption of social life. These events have the 


\section{Maddalena De Lucia et al.}

potential, among other things, to move people in different ways. They make the property or the source of livelihood no longer attractive or impossible [Frankenberg et al., 2014], but, after a long time, the people who have moved away can return and others can come to the disaster area, attracted by new opportunities, possibly created by territorial planning.

According to the definition given by United Nations Organization, a disaster is "a serious disruption of the functioning of a community or a society, involving widespread human, material, economic or environmental losses and impacts, which exceed the ability of affected community or society to cope using its own resources" [UNISDR, 2009]. It causes damage, losses, widespread and long-term effects that are not straightforward to assess. Damage includes the total or partial destruction of physical assets, the disruption of basic services and damages to sources of livelihood in the affected area. Engineers generally provide a physical representation of damage in terms of affected buildings, bridges, lifelines and plants. Costs of asset repair or substitution can then be estimated [Meroni et al., 2017; Rossi et al., 2019a].

Disasters impact is always larger than its immediate effects. It is described by a more comprehensive assessment that adds to the physical damage the human and environmental dimensions, accounting for disease, patterns of population, socioeconomic development and other effects. Systemic interconnections and complexity of modern societies require new approaches to damage analysis and representation with respect to the ones that have been in use so far. Impact, not just damage, of disasters can provide key knowledge regarding several types of failures and indirect loss and effects.

Assessing the impact of a disaster is highly challenging. Usually the assessment is robust on the evaluation of the localized effects, but more demanding is the evaluation of those effects that are widespread and could last for a long period of time [Poljanšek et al., 2017]. Impact assessment is indeed a new approach to the reduction of disaster risks that requires a wider knowledge of multiple parameters. It is priority number one of the Sendai Framework 2015-2030 that refers to the need of understanding disaster risk in all its dimensions in order to derive efficient management strategies.

Among the parameters that shapes disasters' anatomy, life conditions of the population have multiple and interconnected effects. They contribute to exposure in terms of density of individuals and specific vulnerability of societal groups (i.e., age, economic incomes, disabilities, etc.); they also affect the rate of recovery and reshaping of the urban landscape in the post-disaster phase.

This is notably relevant when disasters are related to earthquakes, whose damaging effects are heavily compounded with their impossible forecasting, rapid-onset, short-duration, time-specific and potentially-heavy consequences. Earthquake have long been referred to as the cause of major disasters [Freire and Aubrecht, 2012]. In the 20th century seismic disasters had a 1.87 million deaths toll [Doocy et al., 2013]. They may cause small- to large-scale distress, affecting local communities to the entire society. A seismic disaster may reshape the asset of an entire region and have long term impact.

Italy is a country where seismicity is mostly described by low-to-medium magnitude earthquakes normally occurring in the crust at shallow depth (i.e., within the first $10 \mathrm{~km}$ depth). Strong earthquakes can reach $\mathrm{M}_{\mathrm{W}}=7.1$ [Pino et al., 2000], but have a relatively long return period. Italy has a well and long documented history of strong and moderate magnitude earthquakes resulting into seismic disasters. Seismicity is concentrated along the Apennines chain. The Twentieth century's strongest earthquakes occurred in the southern Italy: the Messina (Sicily) 1908 earthquake ( $\mathrm{M}_{\mathrm{W}}=7.1, \mathrm{I}_{0} 11,80.000$ casualties $)$ - one of the largest seismic disasters in world history - and the 1915 Marsica (Abruzzi region) earthquake ( $\mathrm{M}_{\mathrm{W}}=7.08, \mathrm{I}_{0} 11,30.000$ casualties).

More recently, in the last 50 years, Italy was affected by several seismic disasters with $\mathrm{I}_{0}>8$ (Figure 1): the 1968 Belice earthquake $\left(\mathrm{M}_{\mathrm{W}}=6.41, \mathrm{I}_{0} 10\right)$, the 1976 Friuli $\left(\mathrm{M}_{\mathrm{W}}=6.45, \mathrm{I}_{0} 9-10\right)$, the 1980 Irpinia-Basilicata $\left(\mathrm{M}_{\mathrm{W}}=6.81, \mathrm{I}_{0} 10\right)$, the 1997 Umbria-Marche $\left(\mathrm{M}_{\mathrm{W}}=5.97, \mathrm{I}_{0}\right.$ 8-9), the $2009 \mathrm{~L}$ ' Aquila $\left(\mathrm{M}_{\mathrm{W}}=6.29, \mathrm{I}_{0}\right.$ 9-10), the 2016 Amatrice (August $24^{\text {th }}$, $\mathrm{M}_{\mathrm{W}}=6.20, \mathrm{I}_{0} 10$ ) seismic events [Rovida et al., 2016; Rossi et al., 2019b]. They all caused disruption of the functioning of society and had a widespread impact in the long run.

In this paper we will investigate some of the most significant parameters that could describe disasters' impact in a comprehensive manner, including the long lasting social effects. The goal is to understand collective behavior under conditions of high stress, taking into consideration large-scale events involving entire populations. Thus, we focus on the investigation of the relationship among seismic disasters and their effects on the demography and on the urban structure of distressed land and communities. However, the demographic parameters are not just affected by the disasters themselves: socio-economic factors, policies and programs implemented before, after and during the event are also relevant.

Previous studies have used population dynamics to map human exposure to seismic hazard [Freire and Aubrecht, 2012]. However, our study is a first attempt to include the demographic perspective in the anatomy of a seismic disaster to unfold impact from a different outlook. 


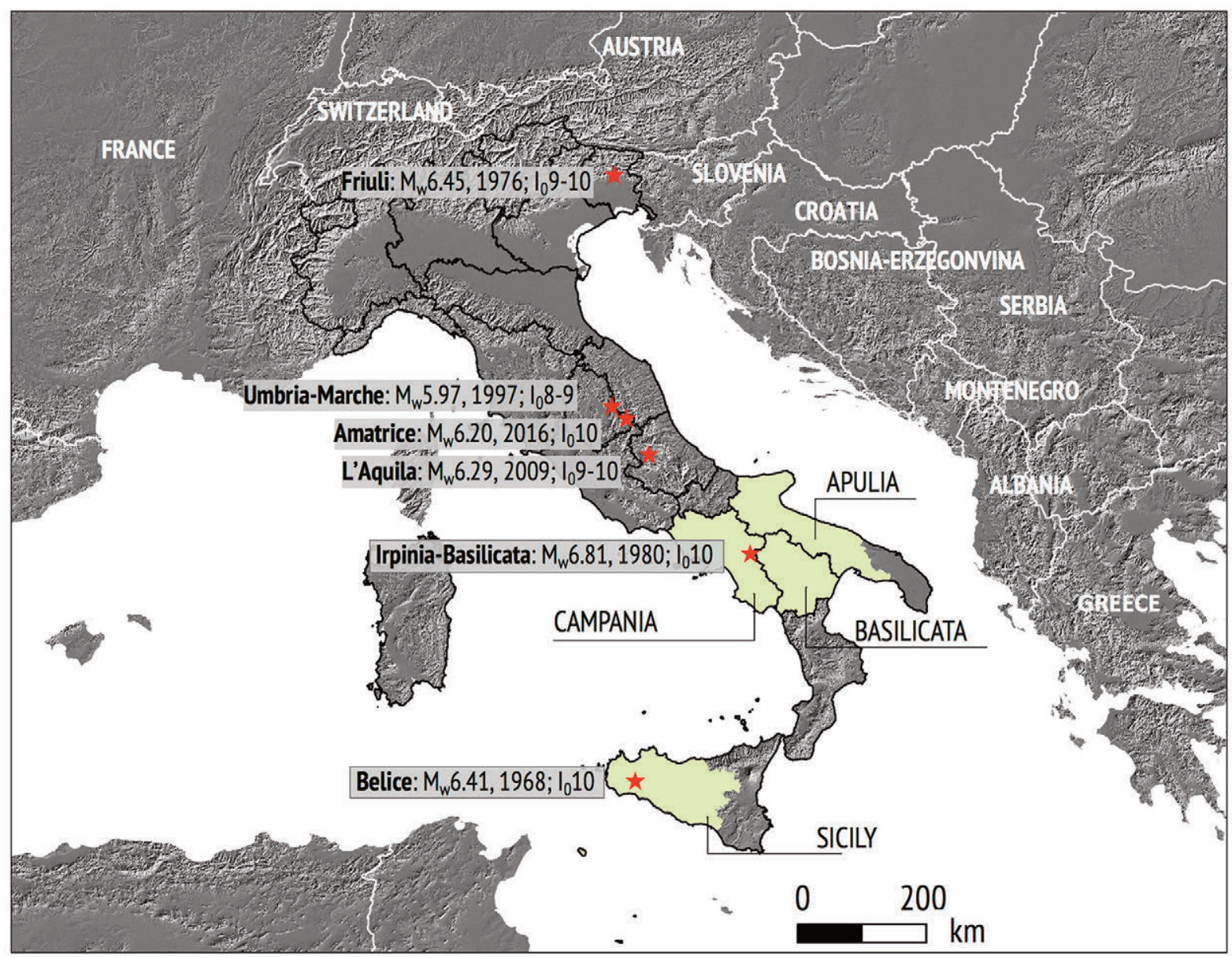

Figure 1. Figure 1 - Last 50 years seismic disasters in Italy. Red stars are epicenter locations. Black borders are the 20 Italian administrative units - regions - upon which the demographic database used in the paper is structured. The 4 regions affected by the seismic disasters discussed in this study are green colored. $\mathrm{I}_{0}$ is the MCS intensity listed in the CPTI15 database (Rovida et al., 2016). For the Amatrice seismic events $\mathrm{M}_{\mathrm{W}}$ and $\mathrm{I}_{0}$ are from Rossi et al. (2019b).

We analyze in details the long term dynamics and structure of population within a large time window across a seismic disaster in relation to different grades of macroseismic intensities evaluated in affected areas. Case studies to test our analytical approach will be two seismic disasters occurred in southern Italy respectively 51 and 39 years ago: the Belice (1968) and the Irpinia-Basilicata (1980) earthquakes.

The two disasters will be described in the light of these research objectives. Also the historical and recent seismicity of Belice and Irpinia-Basilicata will be shortly illustrated. In the third section the methodological aspects will be explained. We present the motivation of the choice of the seismological parameters used and data processing that allows to assign to each municipality a value of macroseismic intensity; demographic data used and indicators computed will be described. Results will then be showed and discussed. More in details, long-period demographic dynamics, changes in age structure of the population and processes of spatial concentration will be analyzed distinctly by groups of municipalities defined according to IMCS. Finally, the conclusions will highlight the original aspects of the pilot study and the relevant observations drawn from the analysis of the two seismic events.

Here and in the following chapters, only values of macroseismic intensity according to the Mercalli-CancaniSieberg scale (MCS) are used [Sieberg, 1930]. To be brief, from now on, in the text Intensity IMCS will be indicated in a short form using I. 


\section{Belice (1968) and Irpinia-Basilicata (1980) seismic disasters}

The Belice (1968) and Irpinia-Basilicata (1980) seismic sequences affected areas that could be considered homogeneous from a socioeconomic and cultural point of view. Indeed, they both belong to southern Italy and are internal areas, with small cities and villages.

Belice is a river valley in western Sicily. Irpinia is a geographical district that corresponds to the province of Avellino, a city in the internal part of the Campania Region (Figure 1). Sicily, Campania, Basilicata and Apulia are four Italian regions, of the twenty territorial and administrative units into which the Italian territory is divided.

There is however a noticeable difference between the two areas. For the Irpinia-Basilicata earthquake even large metropolitan areas such as Naples and its province were involved, and they are classified with I=7, and despite being relatively distant from the epicenter area, they were strongly affected by the impact of the earthquake.

We chose these two earthquakes also because of the availability of strong and robust datasets both for macroseismic intensities and for demographic data and indicators, compiled respectively by Istituto Nazionale di Geofisica e Vulcanologia (INGV) and National Institute of Statistics (ISTAT).

In this chapter we analyze in detail the two case studies, describing also the historical and recent seismicity of the two areas.

Table 1 highlights the main values relating to the human, social and economic losses of the two investigated seismic events. Human (victims, injured) and economic damage are from ASMI [Rovida et al., 2019] database.

Schematic summary of the main features of 1968 Belice and 1980 Irpinia-Basilicata earthquakes

\begin{tabular}{ccccccc}
$\begin{array}{c}\text { earthquake } \\
\text { epicentral area }\end{array}$ & year & casualties (1) & injured (1) & $\begin{array}{c}\text { Damages, based } \\
\text { on funds } \\
\text { allocated (€) (1) }\end{array}$ & $\begin{array}{c}\mathbf{I}_{\mathbf{0}} \text { intensity } \\
\text { MCS (2) }\end{array}$ & $\begin{array}{c}\text { Magnitude } \\
\left(\mathbf{M}_{\mathrm{W}}\right)(\mathbf{2})\end{array}$ \\
\hline Belice & 1968 & 231 & n.d. & 23.5 millions* & 10 & 6.41 \\
\hline $\begin{array}{c}\text { Irpinia } \\
\text { Basilicata }\end{array}$ & 1980 & 2735 & $\begin{array}{c}\text { about } \\
9000\end{array}$ & 23 billions*** & 10 & 6.81 \\
\hline
\end{tabular}

Table 1. In the above table the expression "damage" means a "value of estimated damages based on fund allocated. Data are from: (1) ASMI. Archivio Storico Macrosismico Italiano (Rovida et al., 2019), and (2) CPTI15 (Rovida et al., 2016). *: funds allocated in 1968; **: funds allocated until 1990.

\subsection{Belice area}

\subsubsection{Historical and recent seismicity in the Belice area}

The Belice area is characterized by a low-to-moderate seismicity; only few earthquakes and with very few sources are listed in historical catalogues for this area [Figure 2, data from CPTI15, Rovida et al., 2016]. The region has not suffered strong earthquakes in history except for 1968 earthquake; thus it was not considered a seismic area and thought to be a seismically quiescent region [Barreca et al., 2014]. In Figure 2, earthquakes listed in the CTPI15 catalogue [Rovida et al., 2016] with $\mathrm{I}_{0} \geqslant 7$, are deemed as the highest historical macroseismic intensity mapped in the study area. The recent seismicity is sporadic and of low energy, with very few M>3 seismic events recorded from 1985 until today (Figure 2). 


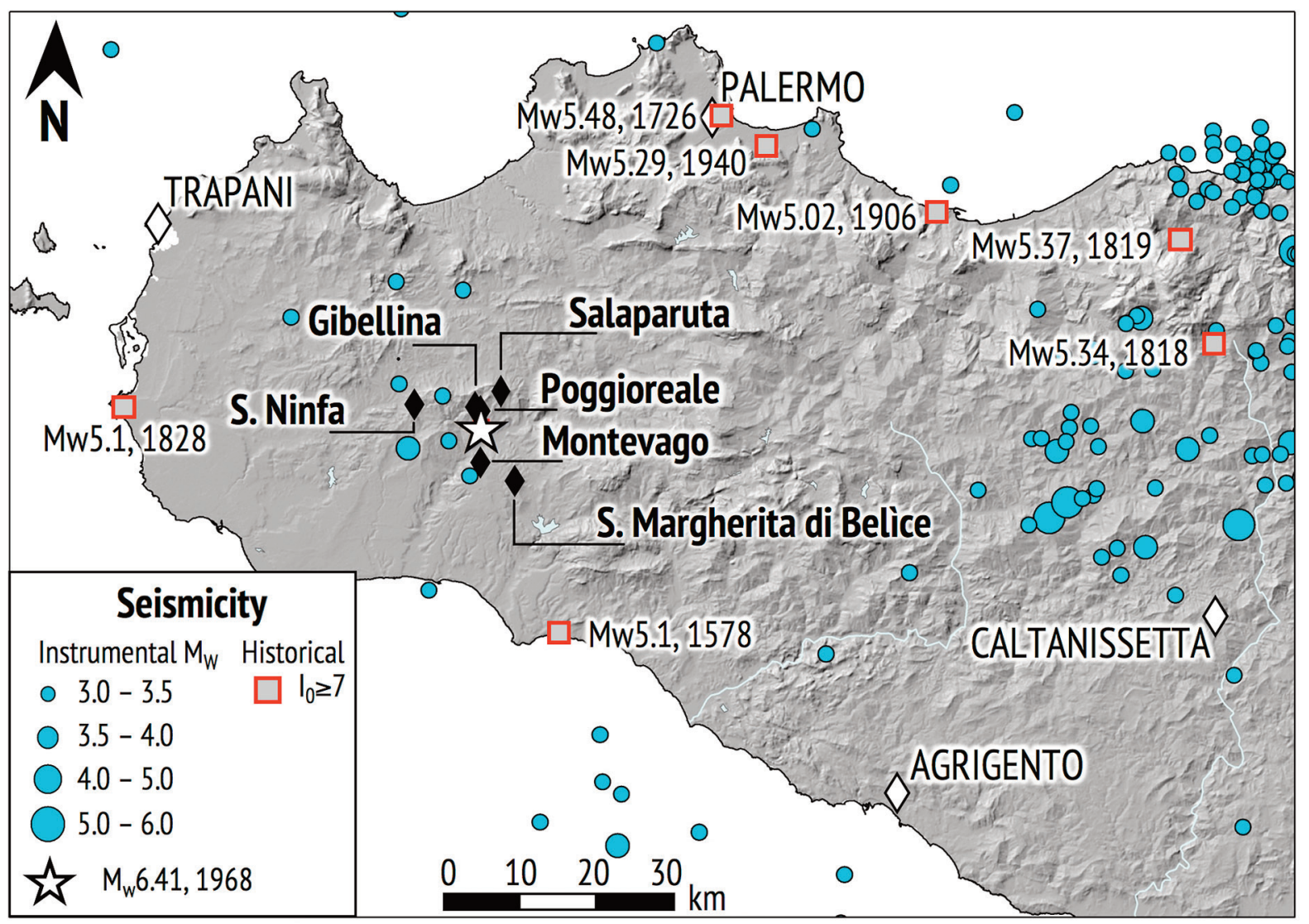

Figure 2. Recent and historical seismicity of central and western Sicily. Plotted instrumental seismicity is that with $M_{W} \geqslant 3$ occurring between 1985 and 2019 (data are from ISIDe: ISIDe working group, 2016); historical seismicity is that with $\mathrm{I}_{0} \geqslant 7$ occurring between 1300 and 1930 (data are from CPTI15, Rovida et al., 2016). White diamonds are provincial capital cities. The white star is the epicentre of the 1968 Belice earthquake and labeled black diamonds are most damaged localities ( $\mathrm{I} \geqslant 9)$. Gibellina, Poggioreale e Salaparuta are plotted in their locations before the 1968 seismic disaster.

\subsubsection{Description of the 1968 Belice earthquake}

The seismic sequence began on January 14,1968 with three strong foreshocks $\left(\mathrm{M}_{\mathrm{W}}=5.1,4.9,4.8\right)$. These first seismic events caused a partial spontaneous evacuation of the houses, also following the indications of the police authority who invited the residents to spend the night outside. Afterwards, the main event $\left(M_{W}=6.41 ; I_{0}=10\right)$ occurred at 2:01 GMT, in the night between 14 and 15 January, and was felt throughout central and western Sicily, and also in Messina and Catania, located at about $200 \mathrm{~km}$. In the following days and months other damaging seismic shocks stroke. The official number of victims was 231 [Guidoboni and Valensise, 2011], but unofficial sources reported more than 400 casualties and more than 1000 injured people [Caldo, 1975]. Displaced people were more than 30,000 [Guidoboni and Valensise, 2011].

The area affected by the heaviest effects was about $1,000 \mathrm{~km}^{2}$ and it includes of the middle and lower basin of the Belice river hills, with the inhabited centers located to the tops.

Macroseismic data points (MDPs) - localities affected by the effects of the earthquake and for which an assessment of macroseismic intensity was made - are 162 (Figure 3). The municipalities of Gibellina, Montevago and Salaparuta were completely destroyed ( $\mathrm{I}=10$ ). Also the village of Poggioreale ( $\mathrm{I}=9$ ) suffered a total devastation; in Santa Margherita di Belice (I=9) 70-80\% of the buildings collapsed, while in Santa Ninfa (I=9) about 50\% was destroyed and the 47\% severely damaged [Rovida et al., 2016; Guidoboni and Valensise, 2011]. 


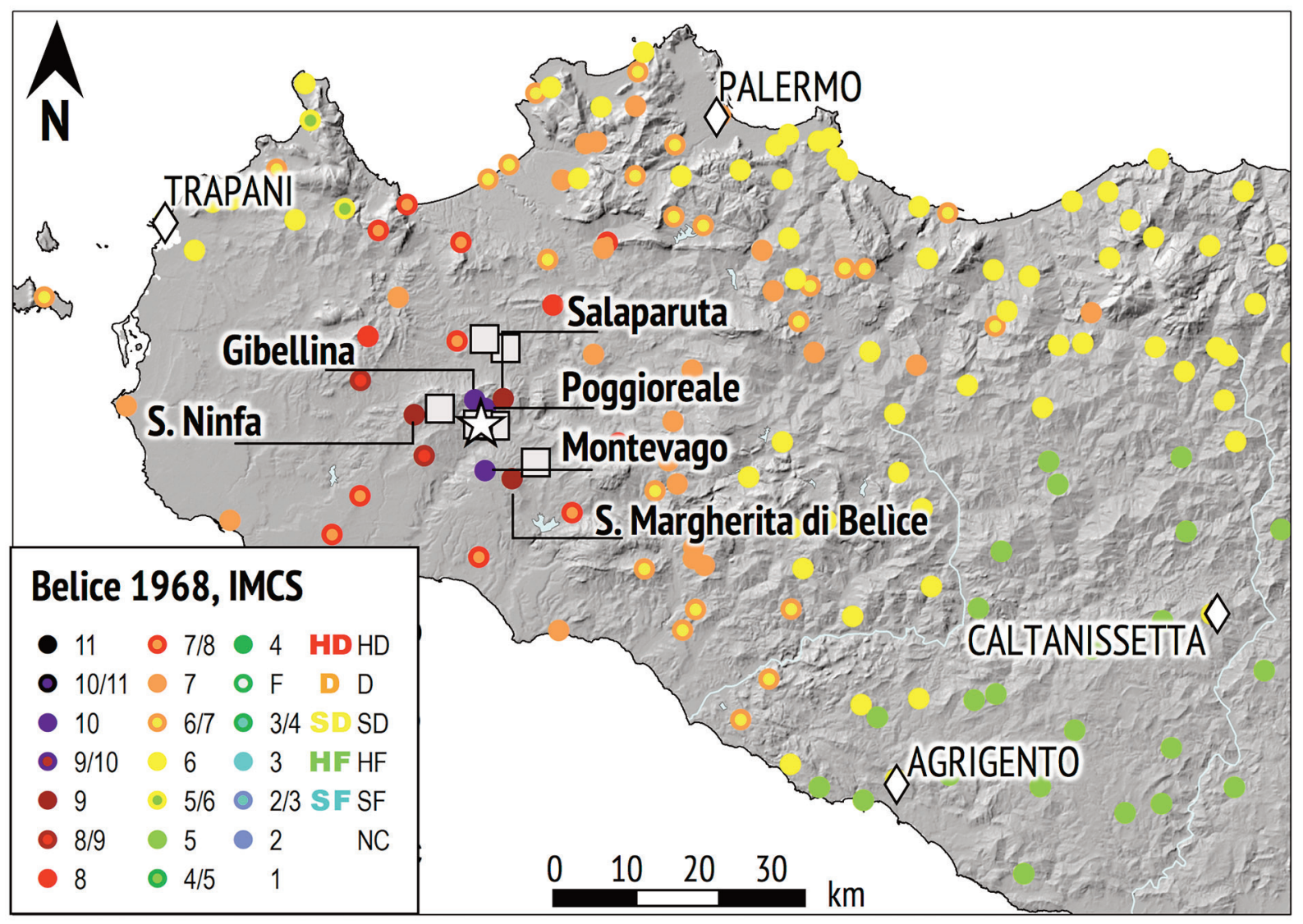

Figure 3. Map of western Sicily with Macroseismic Data Points (MDP) for localities affected by the January 15, 1968 Belice earthquake. White diamonds are provincial capital cities. MCS intensities from CPTI15 database [Rovida et al., 2016] are color coded (see legend). The white star is the epicentre of the 1968 Belice earthquake and labeled are most damaged localities (I $\geqslant 9)$. Light grey squares are major events of the 1968 Belice seismic sequence.

The earthquake also caused significant environmental effects. Landslides, soil cracks, liquefaction, gas emissions and changes in the groundwater regime occurred in Gibellina, Montevago, Partanna, Camporeale, Contessa Entellina.

The high degree of destructiveness of the earthquake was due to a prevailing traditional building construction practice, in masonry and with poor quality sealants and insufficient foundations, the result of a poor economic context based mainly on agriculture, spread in small family plot.

An approximate estimate of the damage made shortly after the main shock put its size at 200 billion of Italian Lira at the time (La Stampa, 23 January 1968). The first rescue operations organized by the government arrived five days after the main shock. In the following days, due to the poor coordination and organization, vehicles and materials destined for the most damaged areas were diverted to peripheral areas. There was a general non-rational and ineffective allocation of government aid.

5235 barracks were built on the orders of the Minister of Public Works. The government seemed to endorse a strategy of land abandonment: free train tickets and passports were issued without formalities. These measures increased the emigration of the Belice population, already under way before the earthquake [Guidoboni and Valensise, 2011]. In some cases, as Gibellina, Montevago, Poggioreale and Salaparuta, the destruction caused displacement rather than the reconstruction: the original historic centers were abandoned and new urban centers, often located at a remarkable distance from the original sites, were built [Scibilia, 2016].

A synopsis of the main seismological features of this earthquake is shown in table 2 . 
Synopsis of the main seismological parameters of the 1968 Belice earthquake

\begin{tabular}{ll} 
What & Earthquake of magnitude $\mathrm{M}_{\mathrm{W}}=6.41 \pm 0.9$ and maximum intensity $\mathrm{I}_{0} 10 \mathrm{MCS}$ \\
\hline When & $\begin{array}{l}\text { The strongest shock occurred on January } 15,1968, \text { preceded and followed by other } \\
\text { lower energy shocks. }\end{array}$ \\
\hline Where & $\begin{array}{l}\text { Belice valley. Provinces of Palermo, Trapani, Agrigento, Sicily (Italy). } 162 \\
\text { Macroseismic Data Points (MDPs). }\end{array}$ \\
\hline Historical seismicity & $\begin{array}{l}\text { The area had been affected in the past by few earthquakes, the strongest of which } \\
\text { occurred in } 1578 \text { and } 1828 . \text { The magnitude of those earthquakes was evaluated of } \\
\mathrm{M}=5.1 \text { and } \mathrm{I}_{0} 7 \mathrm{MCS} .\end{array}$
\end{tabular}

Table 2. The 1968 Belice earthquake at a glance. Data are from Rovida et al., 2016.

\subsection{Irpinia-Basilicata area}

\subsubsection{Historical and recent seismicity in the Irpinia-Basilicata area}

Irpinia and Basilicata areas are located along the southern Apennines where seismicity is made up of frequent events with Magnitude larger than 6. In the last centuries more than ten events with $\mathrm{M}_{\mathrm{W}} \geqslant 6.5$ occurred in the area and had a level of damage $\mathrm{I}_{0} \geqslant 9$ (Figure 4).

Earthquakes with $\mathrm{I}_{0} \geqslant 10$ are listed in table 3 . The last strong earthquakes before the 1980 Irpinia-Basilicata seismic disaster occurred in $1930\left(\mathrm{M}_{\mathrm{W}}=6.67, \mathrm{I}_{0}=10\right)$ and in $1962\left(\mathrm{M}_{\mathrm{W}}=6.15, \mathrm{I}_{0}=9\right)$, within a lifetime from the 1980 event, and might have been still part of local communities background memory.

$I_{0} \geqslant 10$ historical earthquakes in the Southern Apennines from 1000 AD to 1930

\begin{tabular}{cccc} 
Earthquake occurrence & Epicentral area & $\mathbf{I}_{\mathbf{0}}$ & $\mathbf{M}_{\mathbf{W}}$ \\
\hline December 5, 1456 & Central Southern Apennine & XI & 7.19 \\
\hline August 19, 1561 & Vallo di Diano & X & 7.72 \\
\hline June 5, 1688 & Sannio & XI & 6.73 \\
\hline August 8, 1694 & Irpinia-Basilicata & X & 6.56 \\
\hline March 14, 1702 & Sannio-Irpinia & X & 6.75 \\
\hline November 29, 1732 & Irpinia & X-XI & 6.52 \\
\hline August 14, 1851 & Vulture region & X & 7.12 \\
\hline December 16, 1857 & Basilicata & XI & 6.67 \\
\hline July 23, 1930 & Irpinia & X & \\
\hline
\end{tabular}

Table 3. List of the most destructive $\left(I_{0} \geqslant 10\right)$ earthquake occurred in southern Apennines from 1000 AD to 1980, according to CPTI15 (Rovida et al., 2016). 


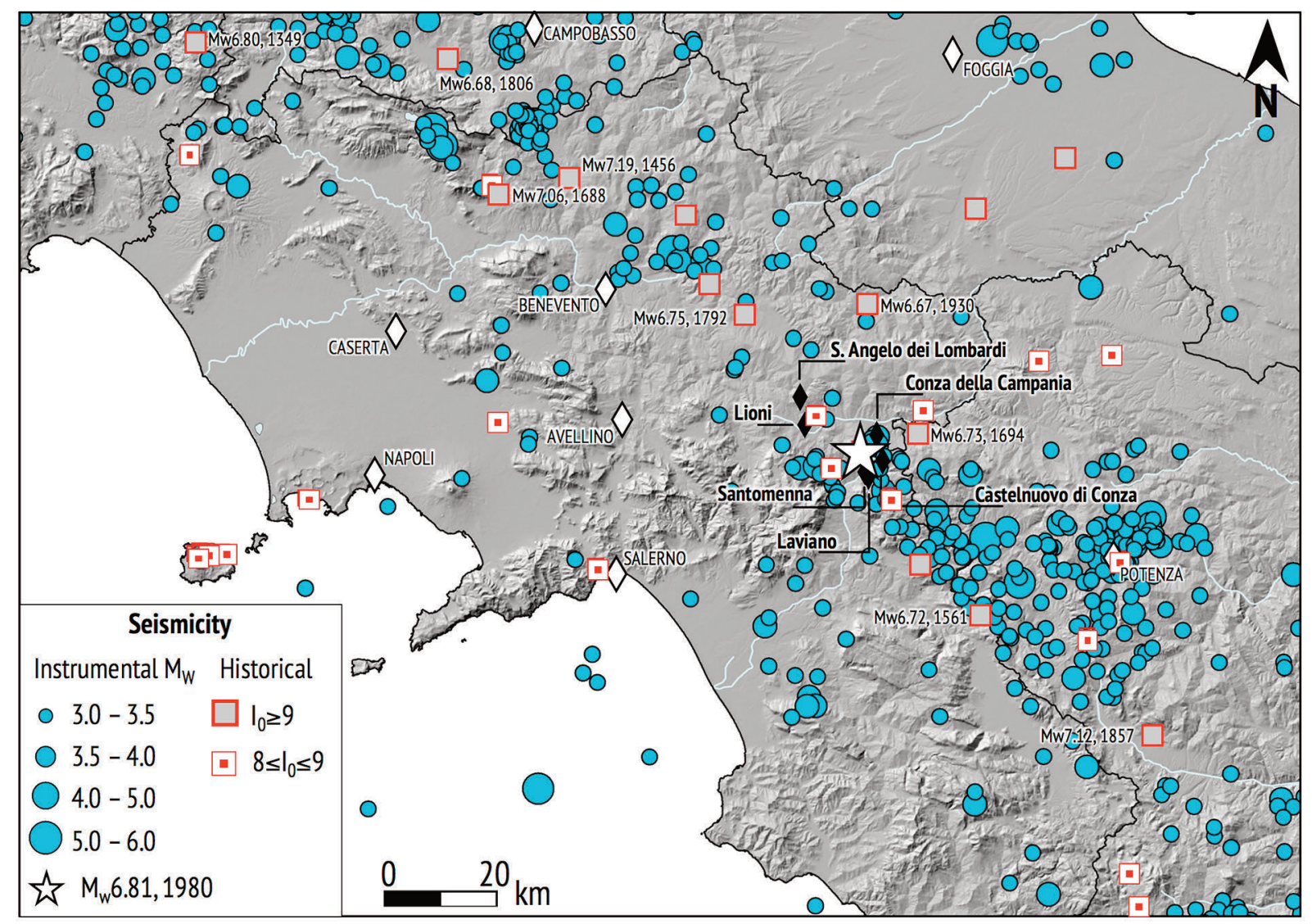

Figure 4. Recent and historical seismicity of central southern Apennines. Plotted instrumental seismicity is that with $\mathrm{M}_{\mathrm{W}} \geqslant 3$ occurring between 1985 and 2019 (data from ISIDe: ISIDe working group, 2016); only historic earthquakes with $\mathrm{I}_{0} \geqslant 9$ (filled grey squares) and $\mathrm{M}_{\mathrm{W}} \geqslant 6.5$ are labelled (data from CPTI15: Rovida et al., 2016). White diamonds are provincial capital cities. The white star is the epicenter of the 1980 Irpinia-Basilicata earthquake and labelled black diamonds are most damaged localities ( $\mathrm{I}=10)$.

Moreover, in the Irpinia-Basilicata area recent seismicity is more frequent and has a larger magnitude than in the Belice area (Figure 4). Within last decades several events with magnitude larger than 4.0 occurred. Very few earthquakes are located north of the area hit by the November $23^{\text {th }}, 1980$ earthquake, while most of the seismicity occurred in the south-eastern sector of the area hit by this earthquake. In this area, seismic sequences, not resulting into seismic disasters, were recorded in February 1983, in July 1986, in May 1990, and in May 1991 [Alessio et al., 1995]. The largest recorded magnitudes are between 4 and 5.

\subsubsection{Description of the 1980 Irpinia-Basilicata earthquake}

Before the November $23^{\text {rd }}$, 1980 Irpinia-Basilicata earthquake, no significant increase in seismicity was registered in the area. The earthquake occurred suddenly, at 6:34 GMT. This event consisted of at least three main rupture episodes occurred at $0 \mathrm{~s}, 18 \mathrm{~s}$, and $40 \mathrm{~s}$ from the first shock, respectively. It was felt all over Italy: southwards down to eastern Sicily, and northwards up to the Po Plain. The most damaging effects were spread over a large area, including the Avellino, Salerno and Potenza provinces, in the Campania and in the Basilicata regions. Total casualties were 2,735, injured were about 9,000, and homeless were 394,000 [Guidoboni e Valensise, 2011]. The seismic sequence went on for several months and was followed also by large events as those occurred on January $16^{\text {th }}, 1981$ $\left(\mathrm{M}_{\mathrm{W}}=5.22\right)$ and on $14^{\text {th }}$ February, $1981\left(\mathrm{M}_{\mathrm{W}}=4.88 ; \mathrm{I}_{0}=7-8\right)$. Heavy damage occurred over an area of about 3,500 $\mathrm{km}^{2}$ [Gizzi et al., 2012], within the Ofanto and Sele valleys. Building stocks were ancient and poor conditions masonry, some of which had been already damaged by previous earthquakes $\left(1910, \mathrm{I}_{0}=9 ; 1930, \mathrm{I}_{0}=10 ; 1962, \mathrm{I}_{0}=9\right)$. 
The overall localities assessed for damage were 1394 [Rovida et al., 2016]. In the epicentral area I=10 was reached in six municipalities (Figure 5): Conza della Campania, Lioni e Sant’Angelo dei Lombardi, Castelnuovo di Conza, Laviano and Santomenna. Around the epicentral area, 9 municipalities were classified with I=9: Calabritto, Caposele, Guardia dei Lombardi, San Mango sul Calore, Senerchia, Teora e Torella dei Lombardi in the Campania region, Pescopagano and Balvano in the Basilicata region (figure 4). Forty-five localities were classified as I=8-9 and I=8. In the Campania region alone, more than $50 \%$ of buildings were damaged and $5 \%$ collapsed. Minor damage, yet still relevant, affected about 450 localities, classified with I ranging from 7 to 6.

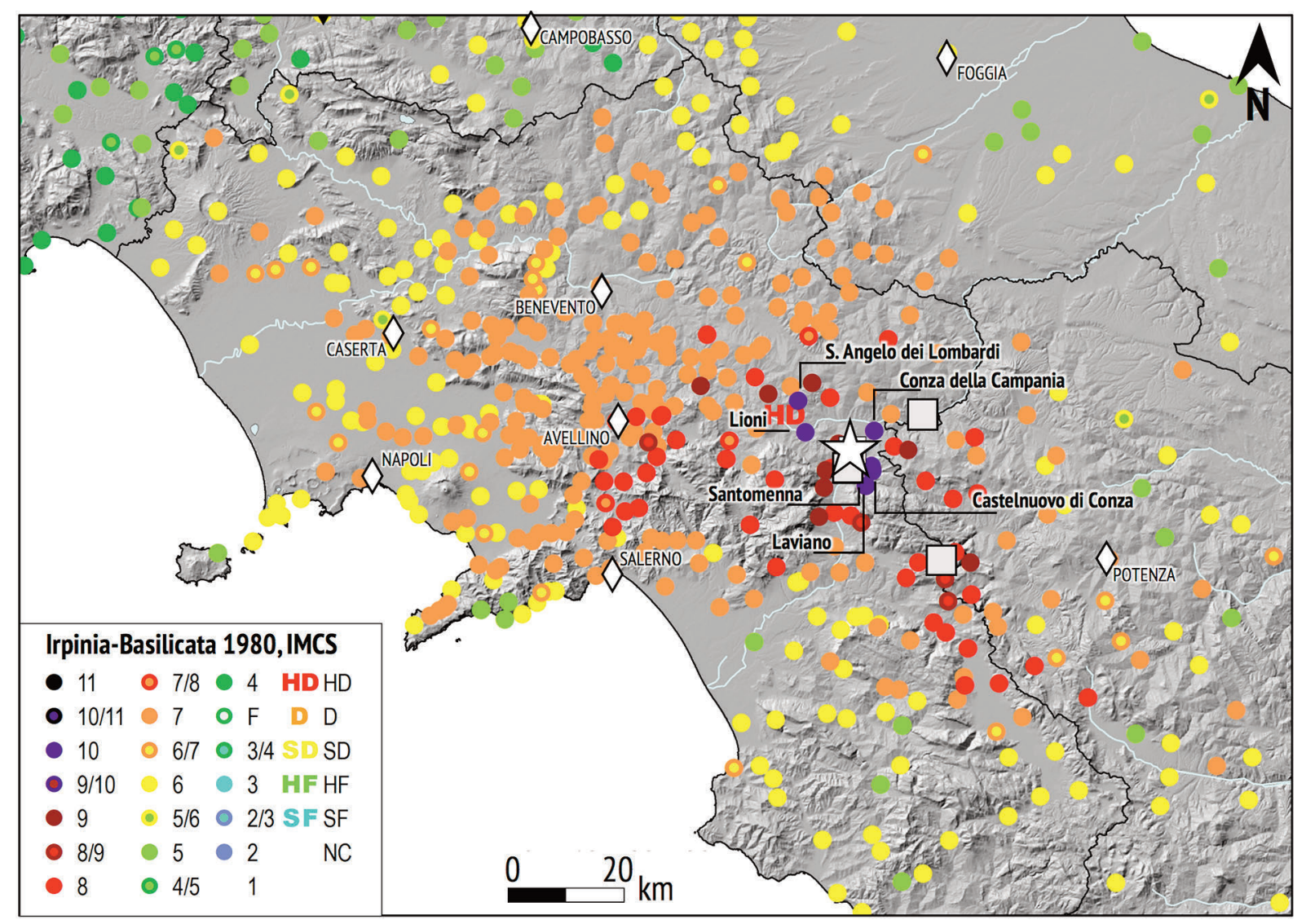

Figure 5. Map of Campania, Basilicata (part), and Apulia (part) regions, with the Macroseismic Data Points (MDP) for localities affected by the November $23^{\text {th }}, 1980$ earthquake. White diamonds are provincial capital cities. MCS intensities from CPTI15 database [Rovida et al., 2016] are color coded (see legend). The white star is the epicenter of the 1980 Irpinia-Basilicata earthquake and labelled are most damaged localities ( $\mathrm{I}=10)$. Light grey squares are the major earthquakes of the 1980 seismic sequence.

The most heavily hit area was the Avellino province, where the epicenters of the main shocks occurred, with all the 119 municipalities damaged, 1507 casualties and 4200 injuries. Here the village of Conza della Campania had 90\% of buildings collapsing and was completely evacuated. Masonry buildings, cultural heritage (i.e., churches, monasteries, defense walls of ancient buildings) and even reinforced concrete buildings in the surrounding area were damaged also heavily [Guidoboni and Valensise, 2011]. The earthquake caused several secondary environmental effects such as surface fractures and cracks, and triggered new and old landslides that hit the villages of Calitri, Caposele, Senerchia and several other localities. The fault that ruptured during the seismic sequence was mapped; it was about $40 \mathrm{~km}$ long with a total slip of about 1 meter along the plane [Pantosti and Valensise, 1993].

The economic asset was that of a rural area, mostly standing on agriculture and small farms. At that time, villages, traditionally affected by emigration, were starting a slow developing process. Investments by emigrants were supporting the startup of small agricultural, industrial and commercial enterprises. The seismic disaster heavily 


\section{Maddalena De Lucia et al.}

impacted this process, up to stopping it, and meanwhile resuming emigration [Guidoboni and Valensise, 2011]. The first rescue operations were delayed, as information on the disaster could not be promptly delivered. A day later, on November $24^{\text {th }}$, the Government declared the state of natural disaster in the affected area and appointed a specific commission to take care of the response phase. 149,000 people were sheltered in trailers, schools, containers and light prefabricated houses. About 50,000 people were hosted in hotels and housing away from the damaged areas. About 30,000 people firstly emigrated. In the city of Naples about 50,000 displaced people were hosted in schools, houses, ships, trailers, container. In the months following the earthquake about 36,000 temporary housing were prepared [Guidoboni e Valensise, 2011].

\section{Synopsis of the main seismological parameters of the 1980 Irpinia-Basilicata earthquake}

\begin{tabular}{|c|c|}
\hline What: & $\begin{array}{l}\text { Earthquake of magnitude } \mathrm{M}_{\mathrm{W}} 6.81 \pm 0.1 \text { and maximum intensity } \mathrm{I}_{0}=10 \text { MCS (Rovida et al., } \\
\text { 2016) }\end{array}$ \\
\hline When: & $\begin{array}{l}\text { the Mw } 6.81 \text { main shock occurred on November } 23 r d 1980 \text {. Several smaller shocks followed. } \\
\text { Two other more major events occurred on January 16th, } 1981\left(\mathrm{M}_{\mathrm{W}}=5.22 \pm 0.1\right) \text { and on } \\
\text { February, 14th, } 1981\left(\mathrm{M}_{\mathrm{W}}=4.88 \pm 0.1 ; \mathrm{I}_{0}=7-8\right) \text {. }\end{array}$ \\
\hline Where: & $\begin{array}{l}\text { Campania, Basilicata and Apulia (only a part) regions, Italy; Avellino, Salerno, Benevento, } \\
\text { Potenza, Foggia provinces. } 1394 \text { Macroseismic Data Points (MDPs). }\end{array}$ \\
\hline Historical seismicity: & $\begin{array}{l}\text { The area, over a radius of } 50 \mathrm{~km} \text { centered on the epicenter, has been affected in the past by } \\
\text { several strong, } M_{W} \geqslant 6.5 \text {, and heavily damaging earthquakes, the last of which, } M_{W}=6.67 \text { in } \\
1930 \text {, just } 50 \text { years before the } 1980 \text { event. }\end{array}$ \\
\hline
\end{tabular}

Table 4. The 1980 Irpinia - Basilicata earthquake at a glance. Data are from Rovida et al., 2016.

\section{Data and methodology}

\subsection{Choice and estimates of seismological parameters for the analysis objectives}

Macroseismic intensity is the seismological parameter describing the effect of an earthquake in terms of physical damage. Intensity scales are very useful when instrumental data are not available: the measure of the local intensity of an earthquake is used to understand the behavior of buildings under seismic stresses.

At any given location, shaking is driven by the seismic energy released by an earthquake and by its propagation to the site. The effects of shaking on buildings and human lives are classified in terms of degrees of intensity on macroseismic scales.

In these scales, each degree is described by a level of shaking suffered by natural and artificial items, generally grouped in four categories: living things (humans-animals), ordinary objects (furniture or domestic items etc.), buildings, and the natural environment (cracks, rock fall etc.). The damage suffered by building stock is used to measure intensity values equal to or greater than grade 6 , generally considered the threshold for initial damage on buildings (permanent effects).

In this study a challenge was to have the macroseismic intensity and demographic data referred to the same spatial object. In the DBMI15 [Locati et al., 2016], localities - meant as populated areas (city, village, down to small district) not necessarily referred to a specific administrative entity - are the fields upon which the database is structured. On the other hand, demographic databases for census collected about 50 years ago have municipalities as primary fields.

In order to couple macroseismic intensity with demographic data, intensity data points referred to localities had to be resampled at municipal level. 
Seismic disasters demographic perspective
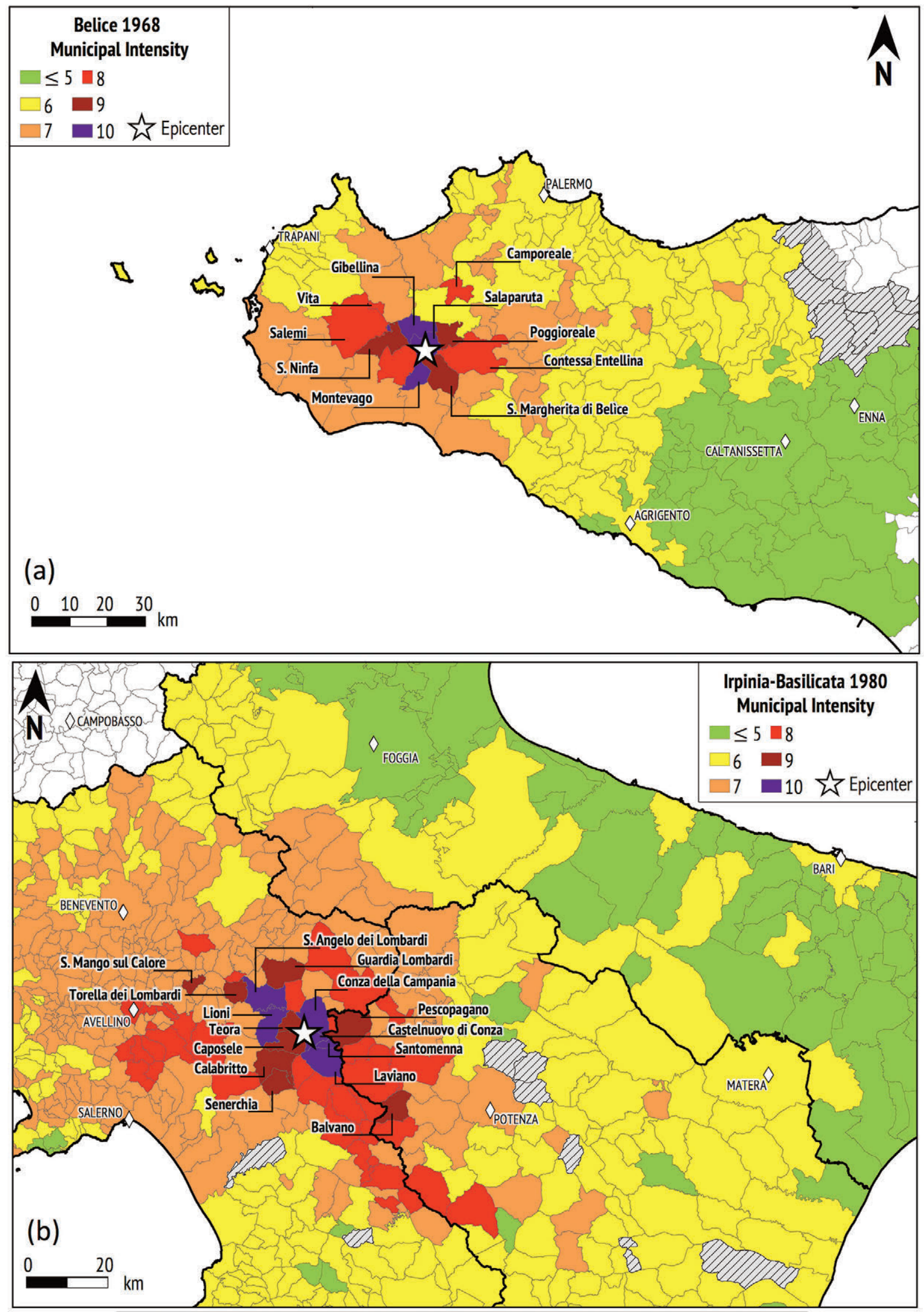

Figure 6. Macroseismic intensities mapped to municipal level for the 1968 Belice (a) and 1980 Irpinia-Basilicata (b) seismic disasters. Municipalities classified as $\mathrm{I}=8, \mathrm{I}=9$ and $\mathrm{I}=10$, for the Belice earthquake, and $\mathrm{I}=9$ and $\mathrm{I}=10$, for the Irpinia-Basilicata earthquake, are labelled. Hatched areas are municipalities excluded from the analysis (see text). White diamonds are provincial capital cities. 


\section{Maddalena De Lucia et al.}

However, there is not a straightforward link between locality and any sort of official administrative entity, including municipality. Nonetheless, since the only mandatory requirement of the MCS scale is that the intensity must be defined on a statistically representative sample of buildings, we could use a statistical approach to retrieve intensity data points at municipal level. This was done applying weighted average and interpolation procedures. For municipalities with more than one intensity data point, we computed the average of the values attributed to the localities enclosed in the municipality, weighted for the number of buildings relevant to each locality.

In case of no point within a given municipality we applied an interpolation procedure. Thus we built a regular grid by applying the Inverse Distance Weighting (IDW) deterministic algorithm [Philip et al., 1982; Watson et al., 1985] on the whole intensity data points (localities).

We used different cells size, depending on the extent of the area. For the 1980 Irpinia-Basilicata earthquake cell size is $1.5 \mathrm{Km}$, whereas for Belice earthquake we used a more detailed grid, with cells size of $0.7 \mathrm{Km}$. However, where gridding interpolation resulted in more than one value within a municipal boundary, we applied a simple arithmetic average.

We define the "municipal intensity" as the macroseismic intensity retrieved for a specific administrative entity, namely the municipality. The results are displayed in Figure 6. In the study areas there are mostly small mountain settlements for which intensity data points are normally well matching the municipalities: only $1 \%$ and $3 \%$ of the data points, respectively in the Belice area and in Irpinia-Basilicata area had to be averaged. When we had no intensity data for a specific municipality, interpolation was computed for $60 \%$ and $32 \%$ of the municipalities in Belice and in Irpinia-Basilicata, respectively.

Macroseismic intensities listed in DBMI15 include values that refers to two consecutive degrees. In principle these are not meant as half degree intensities, but they rather describe damage that cannot strictly be classified as belonging to a degree nor to its consecutive value. We conservatively attributed to these localities the lower limit of the interval, which represents a conservative assumption with respect to the aim of our analysis, because it somehow potentially restricts the area of the disaster. For example, this procedure caused Partanna and Salemi (Figure 6, Belice area) - originally classified with $\mathrm{I}=8-9$ in the DBMI15 database - change to municipal intensity $\mathrm{I}=8$.

Moreover, the weighting and the interpolation procedures produced intensities given by real numbers. Such level of detail is not suitable for the demographic database dimensions and, anyway, far too high for our purpose. For this reason, aiming at having only integer intensity values, we discretized the resampled macroseismic field by assigning the value $\mathrm{I}_{\mathrm{n}}$ to all the data I comprised in the interval:

$$
\mathrm{I}_{\mathrm{n}}-0.5<\mathrm{I} \leq \mathrm{I}_{\mathrm{n}}+0.5
$$

We had to convert intensities for $68 \%$ and $39 \%$ of municipalities for Belice and Irpinia-Basilicata earthquakes, respectively. These values result from summation of municipalities for which interpolation was applied (60\% and 32\% for Belice and Irpinia-Basilicata earthquakes, respectively) and those municipalities with only one macroseismic locality in their territory, whose intensity values are intermediate between two whole numbers (e.g. $\mathrm{I}=8-9$, corrected than in $\mathrm{I}=8$ ). In this cases we assume a discrete, ordinal, value chosen to be the lowest.

\subsubsection{Study area limit}

A crucial issue was to establish the limits of the areas which can be relevant for our study, i.e., we had to define where that specific earthquake did have significant effects that could affect the natural and the anthropic environment, causing changes of the physical landscape, of the economic asset, and of the demographic parameters. To this end, we consider that, for I $>5$ of the MCS intensity scale, people's reaction to the earthquake can be at a turning point. This value is the threshold above which the MCS scale assesses where the earthquake is felt by everybody and non-structural elements of buildings begin to be damaged. We therefore set at I=5 the threshold for our assessment: data below or equal to 5 are considered as background level.

As background level region for the Belice earthquake we limit the study to the provinces of resentment of the earthquake in which there is at least one locality where $\mathrm{I}=6$. Therefore, in Sicily the study area includes only the 
provinces of Palermo, Trapani, Enna, Caltanissetta and Agrigento, excluding eastwards the provinces of Messina, Catania, Siracusa, and Ragusa. For the Irpinia-Basilicata earthquake, the total area of resentment is larger than the study area, but we have restricted the data analysis to three regions (Campania, Basilicata, Apulia). Moreover, in Apulia, we consider only the provinces where there is at least one locality with $\mathrm{I}=6$ (i.e. Foggia, Bari, BAT Barletta/Andria/Trani, and Taranto provinces).

\subsubsection{Damaging overlapping effects}

In order to avoid the overlapping effects by earthquakes occurred in the areas within the studied time-frame, we analyze the seismicity in the period $1951-2011$.

In Sicily two main seismic events occurred: the $\mathrm{M}_{\mathrm{W}}=5.61$ December $13^{\text {th }} 1990$ ( $\left.\mathrm{I}_{\max }=7-8\right)$ and the $\mathrm{M}_{\mathrm{W}}=5.33$ October $31^{\text {st }} 1967$ Nebrodi earthquake $\left(I_{0}=8\right)$ [Rovida et al., 2019].

The December $13^{\text {th }} 1990$ earthquake hits the eastern part of the island and had no damaging effects in all the study area. Similarly, the October $31^{\text {st }} 1967$ Nebrodi earthquake had no large overlapping effects on the study area. But, for the seismologic data to be consistent with demographic analysis, we also exclude nine municipalities belonging to the provinces of Palermo and Enna, where the 1967 Nebrodi earthquake's assessed intensities were higher than those for the 1968 Belice earthquake. These municipalities are Cerami, Nicosia, Pollina, S. Mauro Castelverde, Geraci Siculo, Gangi, Sperlinga, Troina, Gagliano Castelferrato (hatched areas in Figure 6.a).

For the 1980 Irpinia-Basilicata earthquake, the seismic events that may cause overlapping damaging effects were the $\mathrm{M}_{\mathrm{W}}=6.15$ August $21^{\text {st }} 1962$ Irpinia earthquake $\left(\mathrm{I}_{0}=9\right)$, and the $\mathrm{M}_{\mathrm{W}}=5.77$ May $5^{\text {th }} 1990$ Potenza province earthquake $\left(\mathrm{I}_{\max }=7\right)$.

In this pilot study the 1962 earthquake was not taken into account, because it occurred in an area further north and about 20 years before the 1980 Irpinia-Basilicata earthquake. Its effect could be negligible or in any case already partly sealed at the time of the occurrence of the 1980 earthquake.

Detailed aspects can be tackled with a further specific study on the demographic evolution of the Campania Apennines, including areas as Sannio and Irpinia, where the effects of several seismic events are added up.

The May $5^{\text {th }} 1990$ Potenza province earthquake mostly hit the southern edge of the study area. We exclude from the demographic analysis, the municipalities for which the 1990 Potenza province earthquake had intensity higher than those for the 1980 Irpinia-Basilicata earthquake. These municipalities are Cancellara, Missanello, Sacco, Pietragalla, Serre, Vaglio Basilicata, Castelmezzano, Tursi (hatched areas in Figure 6.b).

\subsection{Demographic measures of population dynamics, structures and spatial concentration}

In this pilot study, data from the last 7 population censuses (from 1951 to 2011) are used. The same are provided by the Italian National Institute of Statistics (ISTAT). In particular, we refer to the information on residents in the four regions considered (Sicily for 1968 Belice earthquake and Campania, Apulia, and Basilicata for the 1980 IrpiniaBasilicata earthquake) broken down by municipality of residence, gender and age groups. These data allow to examine the inter-censual demographic dynamics [average annual growth rates, see Livi Bacci, 1981], the evolution of the age structure [ageing index and child-woman ratio, see Livi Bacci, 1981] and the level of spatial concentration [Gini index, see McKibben and Faust, 2004] of the populations residing in the municipalities, according to the classes of macroseismic intensity (I) for the two earthquakes mentioned above (see section 3.1). This approach allows us to understand if there is any association between population dynamics and demographic structure, on the one hand, and the impact of earthquakes, expressed in the metric of the seismic intensity, on the other. All the municipalities in the study area that have only suffered minor damage from the seismic event (a cluster of municipalities with I lower than or equal to 5) will also constitute a category of comparison.

The data used here do not allow to examine the short-term effects of earthquakes on the natural (and migratory) dynamics of populations, and to distinguish the overall variation of the population in the natural and migratory components. This will only be possible by integrating the data used here with those on births and deaths coming from the Municipal Population Registers (MPRs) due to post-censual update and/or inter-censual reconstructions of the population. Such integration will allow calculate crude rates (births and deaths) and natural growth rates, as 


\section{Maddalena De Lucia et al.}

well as to estimate the inter-censual demographic variations due to the migratory component. The municipal archive with these data for the period 1952-2011 is being completed and revised. For this reason, the data used are only those on the populations at the census surveys: 1951, 1961, 1971, 1981, 1991, 2001 and 2011. These data provide just 'general' (or indirect) information on the association between the intensity of the earthquake and population dynamics in the medium-long term.

Anyhow it should be noticed that the data used here, albeit with the limitations described, allow to make diachronic comparisons 'correct' from a geographical and demographic point of view, being reconstructed to the municipal geographies of 2011.

As far as the variation of the population in an intercensal period is concerned, the mean annualized growth rate (r) is calculated, which is equal to the natural logarithm of the ratio between the resident population at the two subsequent censuses $\left(\mathrm{N}_{\mathrm{t}}\right.$ and $\left.\mathrm{N}_{0}\right)$ divided by the extent of the time interval between the two surveys expressed in years (t). In formula:

$$
r=\left[\ln \left(N_{t} / N_{0}\right)\right] / t
$$

As for the indexes related to demographic structures, the following measures have been computed: (a) ageing index, given by the ratio between the elderly population (65 years and over) and the young population (under 15 years); (b) child-woman ratio, equal to the ratio between children under 5 and women in childbearing age (aged 1544). The first index summarizes the aging process of the population, the second is also an indirect measure of the level of fertility.

Finally, to measure the level and dynamics of spatial concentration of resident population we have used the Gini index $(\mathrm{G})$. The Gini index is a measure of inequality of a distribution. By computing the Gini Index, the questions we try to answer are: is the population of the different class of macroseismic intensity dispersed or concentrated? What are the levels of spatial concentration of pre and post-earthquakes? The Gini index has been computed as follows:

$$
\mathrm{G}=\left(\sum_{i=1} x_{i} y_{i+1}\right)-\left(\sum_{i=1} x_{i+1} y_{i}\right)
$$

Where $\mathrm{x}_{\mathrm{i}}$ is the cumulative proportion of population residing in municipality $\mathrm{i}$ and $\mathrm{y}_{\mathrm{i}}$ is the cumulative proportion of surface of municipality i. For the purposes of the study we had to use total area of each municipality, since data on inhabitable area are not available. The Gini index varies from 0 (no concentration) to 1 (maximum concentration).

It was not possible to use the ISTAT data referred only to the inhabited areas within each municipality, because these data are not available for censuses from 1951 to 1991. For the sake of consistency of analysis it was decided to use only the available data since 1951 .

\section{Demographic and structural dynamics before and after the earthquake}

\subsection{Some geo-demographic aspects}

The total number of municipalities of the four regions is equal to 1,330 in which, in 2011, more than 15 million people reside, about $25 \%$ of the population resident in Italy in the same year. It is a geographically very broad area, just under 70 thousand square kilometers, equal to a national share, in 2011, of $23 \%$, but which rises to over $55 \%$ if referring only to the so-called 'Mezzogiorno' (southern Italy plus island regions). Due to the reasons explained in the previous sections, the analysis considers a subset of 997 municipalities (76\% of the total), corresponding to a population of slightly less than 12 million inhabitants in 2011. All the figures and analysis that follows, with the exception of the ones of section 4.4, refer to this sub sample of municipalities. 
The distribution of municipalities and of the population resident in the four regions is very heterogeneous also as a result of the different area extension of each regional reality. Of course, many other factors than purely geographical ones contribute to define the different settlement geographies and their dynamics. We refer to factors related to the geomorphologic characteristics of the territories, such as the number of mountain and lowland municipalities, as well as those related to the different levels of accessibility of the territories. These factors, together with others (socio-economic ones), have guided the processes of distribution and redistribution of the Italian regional populations from the great urbanization of the fifties and sixties to the subsequent phases of peri-urban and suburban growth [Bottai and Benassi, 2016]. The same factors, together with demographic change on local spatial scales, are the basis of the dual development of territories. A process that if not adequately managed normally implies rural depopulation and marginalization and the rise of socio-economic inequalities between different territorial context [Beale, 1964; ESPON, 2017].

The region with the highest number of municipalities considered in the analysis is the Campania, 549 units representing $54.3 \%$ of the total number of municipalities analyzed. Sicilia follows with 182 municipalities (18.3\%), then comes Apulia, 141 municipalities (14.1\%), and finally Basilicata, 125 municipalities (12.5\%).

Grouping Campania, Apulia, and Basilicata, the number of the considered municipalities rises to 815, almost $82 \%$ of the total. The distribution of the resident population in the selected municipalities is quite similar. The most populous region in 2011 is Campania, which is close to 5.8 million residents ( $49.3 \%$ of the total population), then Apulia, 2.8 million residents (24.4\%), Sicily, 2.5 million residents (22.0\%), and Basilicata, just over half million residents in $2011,4.8 \%$ of the total population resident in the selected municipalities belonging to the four regions in 2011. With the sole exception of section 4.4, in the following analysis almost all the population of Campania and Basilicata will be considered (respectively 99.9 and $97.5 \%$ ), $70.3 \%$ of that of Puglia and $50.4 \%$ of that of Sicily at 2011 census.

We focus now on the distribution of municipalities by MCS macroseismic intensities for the two different geographical areas (Sicily; Campania, Apulia, and Basilicata). For the 1968 Belice earthquake, about half of Sicilian municipalities considered in the analysis, $47.3 \%$, were classified in the $I \leqslant 5$ class, while the share of municipalities classified in the I $\geqslant 9$ class (i.e., $9-10$ category in figures $7,9,10,11$ ) was equal to $3.3 \%$. For the 1980 Irpinia-Basilicata earthquake, considering Campania, Apulia, and Basilicata jointly, the $44.0 \%$ of the selected municipalities is concentrated in the class $I=6$, while the shares of municipalities of the same 'macro region' in the classes $\mathrm{I} \leqslant 5$ and $\mathrm{I}=7$, are equal to $16.7 \%$ and to $32.6 \%$ respectively. Intra-regional variability is quite relevant: in Campania, the selected municipalities in the highest macro seismic intensity class ( $I \geqslant 9)$ account for $2.4 \%$ of the total of the region, but in the same class only $1.6 \%$ of the municipalities of Basilicata fall, while no municipality in Apulia. In the latter region $68.1 \%$ of the municipalities are concentrated in the lowest macroseismic class (I $\leqslant 5)$, which instead records much lower shares in Basilicata (9.6\%) and, above all, in Campania, just $5.1 \%$.

The distribution of the population by municipal macroseismic intensity follows similar patterns. With reference to the 1951, in Sicily, the population was mainly concentrated in the I=6 class, 50.3\% (1.2 million) of the regional population resident in the municipalities selected for the analysis. On the other hand, the share of the population living in municipalities with a high seismic intensity is quite limited: $1.9 \%$ in $\mathrm{I}=8$ class, $1.3 \%$ in I $\geqslant 9$ class (Table 5). Considering Campania, Apulia, and Basilicata, the share of the population residing in the areas with the greatest seismic intensity was already in 1951 residual: $0.8 \%$ in I $\geqslant 9$ class and $2.9 \%$ in I $=8$ class, for a total population of less than 270 thousand inhabitants. The population shares that in 1951 resided in the other intensity classes of municipalities are more substantial, ranging from just over a third (34.8\%; 2.5 million) for I=6 to $37.9 \%$ (2.7 million) for I=7 class and, finally, to about $24 \%$ (1.7 million) for the lower class $(I \leqslant 5)$. Naturally, there are important differences between the regions that make up this macro area. In this regard, we limit ourselves to pointing out that in Campania, as of 1951, the majority of the regional population resident in the municipalities selected for the analysis, almost 59\%, lived in municipalities belonging to $I=7$ class. However, the highest seismicity classes $(I=8$ and $I \geqslant 9$ ) collected a total of more than $5 \%$ of the regional population resident in the selected municipalities. In Apulia the vast majority of the regional population resided in municipalities belonging to $I \leqslant 5,68.9 \%$, while in Basilicata $62 \%$ of the regional population was concentrated in municipalities classified as I $=6$ class but more than $7 \%$ resided in municipalities with high macroseismic intensity ( $I=8$ and $I \geqslant 9)$. 
Geo-demographic characteristics of (selected) municipalities by 5 IMCS classes. Sicily, Campania, Apulia, and Basilicata, 1951-2011.

\begin{tabular}{|c|c|c|c|c|c|c|}
\hline \multirow{2}{*}{$\begin{array}{l}\text { Class of macroseismic } \\
\text { Intensity (MCS) }\end{array}$} & \multicolumn{2}{|c|}{ Municipalities } & \multicolumn{2}{|c|}{ Population 1951} & \multicolumn{2}{|c|}{ Population 2011} \\
\hline & No. & $(\%)$ & No. & (\%) & No. & $(\%)$ \\
\hline \multicolumn{7}{|c|}{ Sicily } \\
\hline$\leqslant 5$ & 55 & 30.2 & 725,013 & 30.3 & 633,951 & 25.1 \\
\hline 6 & 86 & 47.3 & $1,201,669$ & 50.3 & $1,431,154$ & 56.7 \\
\hline 7 & 30 & 16.5 & 384,497 & 16.1 & 405,996 & 16.1 \\
\hline 8 & 5 & 2.7 & 45,842 & 1.9 & 29,177 & 1.2 \\
\hline$\geqslant 9$ & 6 & 3.3 & 31,899 & 1.3 & 22,173 & 0.9 \\
\hline Total considered (a) & 182 & 100.0 & $2,388,920$ & 100.0 & $2,522,451$ & 100.0 \\
\hline Regional total & 390 & & $4,486,749$ & & $5,002,904$ & \\
\hline \multicolumn{7}{|c|}{ Campania, Apulia and Basilicata } \\
\hline$\leqslant 5$ & 136 & 16.7 & $1,703,988$ & 23.6 & $2,250,728$ & 24.5 \\
\hline 6 & 359 & 44.0 & $2,517,710$ & 34.8 & $3,453,601$ & 37.6 \\
\hline 7 & 266 & 32.6 & $2,739,365$ & 37.9 & $3,226,794$ & 35.2 \\
\hline 8 & 39 & 4.8 & 212,743 & 2.9 & 212,300 & 2.3 \\
\hline$\geqslant 9$ & 15 & 1.8 & 56,562 & 0.8 & 32,367 & 0.4 \\
\hline Total considered (a) & 815 & 100.0 & $7,230,368$ & 100.0 & $9,175,790$ & 100.0 \\
\hline Regional total & 940 & & $8,194,335$ & & $10,397,412$ & \\
\hline \multicolumn{7}{|c|}{ Campania } \\
\hline$\leqslant 5$ & 28 & 5.1 & 82,068 & 1.9 & 100,827 & 1.7 \\
\hline 6 & 240 & 43.7 & $1,495,428$ & 34.5 & $2,393,377$ & 41.5 \\
\hline 7 & 236 & 43.0 & $2,537,638$ & 58.5 & $3,051,589$ & 53.0 \\
\hline 8 & 32 & 5.8 & 175,455 & 4.0 & 188,018 & 3.3 \\
\hline$\geqslant 9$ & 13 & 2.4 & 49,510 & 1.1 & 28,484 & 0.5 \\
\hline Total considered ${ }^{(a)}$ & 549 & 100.0 & $4,340,099$ & 100.0 & $5,762,295$ & 100.0 \\
\hline Regional total & 551 & & $4,346,264$ & & $5,766,810$ & \\
\hline \multicolumn{7}{|c|}{ Apulia } \\
\hline$\leqslant 5$ & 96 & 68.1 & $1,573,761$ & 68.9 & $2,105,319$ & 73.9 \\
\hline 6 & 35 & 24.8 & 647,671 & 28.4 & 721,330 & 25.3 \\
\hline 7 & 10 & 7.1 & 62,142 & 2.7 & 23,098 & 0.8 \\
\hline 8 & 0 & 0.0 & 0 & 0.0 & 0 & 0.0 \\
\hline$\geqslant 9$ & 0 & 0.0 & 0 & 0.0 & 0 & 0.0 \\
\hline Total considered (a) & 141 & 100.0 & $2,283,574$ & 100.0 & $2,849,747$ & 100.0 \\
\hline Regional total & 258 & & $3,220,485$ & & $4,052,566$ & \\
\hline \multicolumn{7}{|c|}{ Basilicata } \\
\hline$\leqslant 5$ & 12 & 9.6 & 48,159 & 7.9 & 44,582 & 7.9 \\
\hline 6 & 84 & 67.2 & 374,611 & 61.7 & 338,894 & 60.1 \\
\hline 7 & 20 & 16.0 & 139,585 & 23.0 & 152,107 & 27.0 \\
\hline 8 & 7 & 5.6 & 37,288 & 6.1 & 24,282 & 4.3 \\
\hline$\geqslant 9$ & 2 & 1.6 & 7,052 & 1.2 & 3,883 & 0.7 \\
\hline Total considered ${ }^{(\mathrm{a})}$ & 125 & 100.0 & 606,695 & 100.0 & 563,748 & 100.0 \\
\hline Regional total & 131 & & 627,586 & & 578,036 & \\
\hline
\end{tabular}

Table 5. Some geo-demographic characteristics of (selected) municipalities by 5 IMCS classes. Sicily, Campania, Apulia, and Basilicata, 1951-2011. Note: (a) In the case of Sicily, all the municipalities of the eastern provinces (Catania, Messina, Ragusa and Syracuse) and other nine municipalities are excluded from the analysis. Two municipalities are excluded from the analysis in Campania, the same holds for all the municipalities of the provinces of Brindisi and Lecce in Apulia and six municipalities in Basilicata (see cap. 3.1). Source: our elaboration on Istat census data from the information system "ottomila census" (www.ottomilacensus.it). 
In the decades that follow, these settlement patterns consolidate themselves. In Sicily the regional demographic growth recorded from 1951 to 2011 is completely attributable to municipalities where the 1968 earthquake resulted into I=6 and I=7. In 2011 in Campania, in the municipalities with the highest macroseismic intensity, $\mathrm{I}=8$ and $\mathrm{I} \geqslant 9$, respectively only $3.3 \%$ and $0.5 \%$ of the regional population resides. In the municipalities belonging to I=7 class lives $53.0 \%$ of the population residing in the municipalities selected for the analysis. These three types of municipalities, together with those classified in the I $\leqslant 5$ class, see a decrease in the shares of resident population compared to 1951. This contraction was particularly intense in the I=7 class, where the percentage of residents passes from $58.5 \%$ in 1951 to $53.0 \%$ in 2011 . On the contrary, the municipalities in $\mathrm{I}=6$ class recorded a significant increase in the resident population, from $34.5 \%$ to $41.5 \%$. In Apulia, the increase in the regional population recorded in the sixty years analyzed is attributable to the demographic dynamics recorded by the municipalities with the lowest seismic intensity. The share of resident population living in the $I \leqslant 5$ selected municipalities grew from $68.9 \%$ to $73.9 \%$ while the municipalities belonging to $\mathrm{I}=6$ class and $\mathrm{I}=7$ class recorded significant contractions in the share of resident population: from $28.4 \%$ to $25.3 \%$ and from $2.7 \%$ to $0.8 \%$ respectively. In Basilicata, in the face of a slight but significant contraction in the regional population, the only municipalities that grow in terms of share of regional

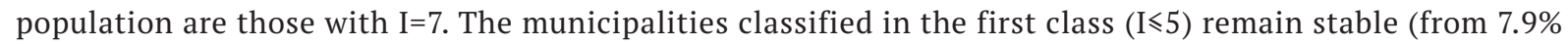
in 1951 to $7.9 \%$ in 2011). Considered together the three regions of Campania, Apulia and Basilicata, a rather clear picture emerges: the share of population resident in the municipalities in comparative higher class of seismic intensity (i.e. those classified with $\mathrm{I}=7, \mathrm{I}=8, \mathrm{I} \geqslant 9$ ) decrease, from 1951 to 2011 ; the opposite is true for the municipalities with reduced seismic intensity ( $\mathrm{I} \leqslant 5$ and $\mathrm{I}=6)$.

From these first data, it seems that a picture emerges that can be traced back to the vicious circle of territorial marginality and vulnerability. Local contexts where in 1951 there was already little population are those falling mainly in higher I classes and match those that have lost population. Such depopulation process highlights a complex demographic phenomenon that contribute to impoverish territories, consequently increasing their vulnerability to exogenous shocks (including natural ones) and having significant negative implications in socioeconomic terms [Lasanta et al., 2017].

The importance of the demographic dimension of the municipalities both in absolute terms and relative to the macroseismic class of belonging is an element that must be considered in the analysis. This is especially true for high macroseismic classes (I $\geqslant 7$ ). An emblematic case is that of the municipality of Naples, which represented 37\% in 1951 and 30\% in 2011 of the population of all the municipalities of Campania, Apulia, and Basilicata of the same I class (I=7). This is not the case for the other metropolitan municipalities included in the analysis, such as Bari and Palermo, which are both classified in $\mathrm{I}=6$ class. There are also smaller urban assets, in absolute terms, that play a significant role with respect to the seismic category they belong when referring to the regional context. Potenza, for example, has an I=7 and a reduced demographic size, below 70 thousand people in 2011, but in the same year it represents $54 \%$ of the population of the municipalities $I=7$ class in the Basilicata region. Even different is the case of Avellino, in Campania region, which with more than 50,000 inhabitants represents more than $25 \%$ of the population of the same macroseismic class ( $\mathrm{I}=8$ ) of the regions of Campania, Apulia, and Basilicata in 2011. Precisely in consideration of these aspects, and in order to take them into account to some extent, the analysis was conducted for all categories of I both gross and net of the municipality of Naples.

\subsection{Differential demographic growths}

The analysis of the values of the demographic growth rates in the inter-censual periods before and after the seismic events should allow to assess: a) whether before the disaster the demographic dynamics of the most affected municipalities were greater, equal, or lower than those of the other selected municipalities in the territory considered; b) whether after the seismic event there was a gap in the demographic growth rates between the most affected municipalities and the other municipalities in the region, and in what direction. In particular, a lower growth or a greater demographic decrease of the municipalities most affected could be expected if the negative effects of the event had not been compensated by the subsequent interventions. The exact opposite is expected if fast recovery, possibly in response to efficient reconstruction and measures in support of new employment opportunities attracting population, occurred. 


\section{Maddalena De Lucia et al.}

We observe that both seismic disasters stroke municipalities with a less favorable demographic dynamics compared to others in the study area. Before the 1968 earthquake, most affected (I 8) municipalities of Sicily had already a noticeable decrease in population that continued, although with a lower gradient, in the most recent decades (Figure 7.a). Only the group of municipalities where the earthquake had a comparatively minor impact (i.e., I=7) recorded in the last decades a positive demographic growth, equal (or greater) to that of municipalities that were little or not at all affected by the event. It should be noted that all the municipalities not affected by the earthquake $(\mathrm{I} \leqslant 5)$ recorded a negative variation in population and below the overall average in all the decades considered, both before and after the earthquake. Then it would be valid to assume that the municipalities with a significant but not very strong impact ( $\mathrm{I}=7$ ) may have benefited from the interventions related to the earthquake.

The situation in the three regions affected by the Irpinia-Basilicata earthquake is somehow similar (Figure 7.b). The municipalities most affected by the earthquake of 1980, in the decades before the earthquake, had a negative ( $\geqslant 9$ class) or poorly positive ( $\mathrm{I}=8$ class) demographic dynamic, anyhow lower than that of the other municipalities in the study area. In the next 30 years their rate of increase remains lower than that recorded by the municipalities less or not at all affected by the earthquake, except for I=8 in the 1981-1991. However, it should be noticed that, unlike what observed for the Belice earthquake, the municipalities classified at the intermediate level (i.e. I=7) show a mostly negative trend over the 60 years considered. If before the event they had positive levels of population growth and similar to those of the municipalities not affected by the earthquake, after the event they recorded only negative values, although less marked when compared to those of most affected (I $\geqslant 8)$ municipalities The situation changes if we exclude from the analysis the municipality of Naples, which at the beginning of the considered period represents alone about $37 \%$ of the population of the municipalities of the I=7 group. In this case the growth rate of the remaining municipalities is greater than the average of the entire area (i.e., the three southern regions) and more or less in line with what was observed in Sicily for the cluster of municipalities with $\mathrm{I}=7$ in comparison with the other clusters.
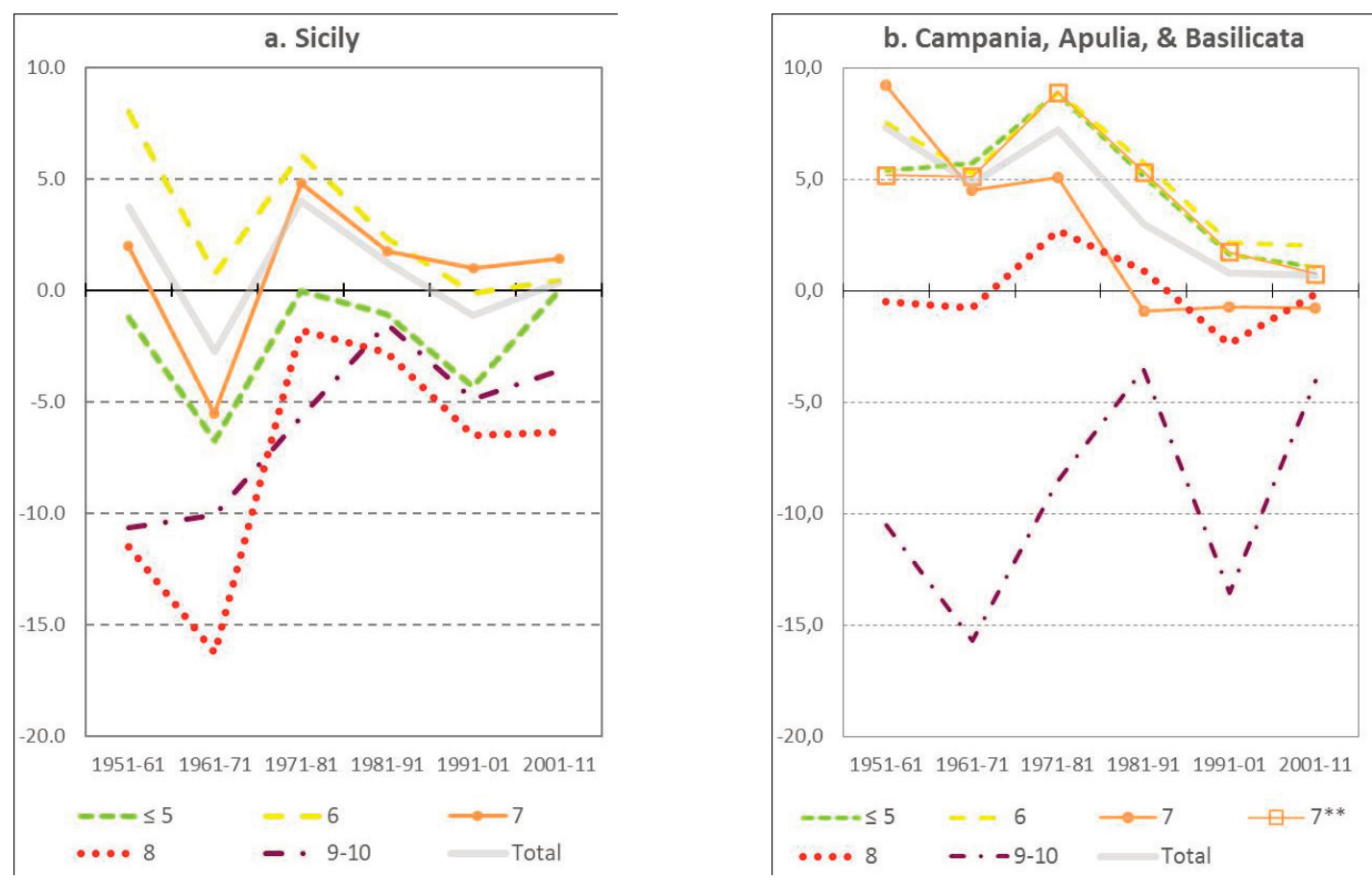

Figure 7. Inter-censual growth rates of population (annual mean values per 1,000 inhabitants) according to the intensity classes used in this study. 9-10 class includes both I=9 and I=10 municipalities. Color code is the same than in figure 6. Municipalities of Sicily (a) and of Campania, Apulia, and Basilicata together (b), for the time period 1951-2011. In both panels only the municipalities selected for the analysis are considered (see note in Table 5). In $b$. the line $7^{* *}$ identifies the $\mathrm{I}=7$ class without the municipality of Naples. Source: our elaboration on Istat census data from the information system "ottomila census" (www.ottomilacensus.it). 
We computed the total post-event population growth and mapped ifor each municipality of the two areas, comparing them with municipal intensity maps (Figure 8). Since demographic data are stored only every 10 years, for the two events we had to set as post-event time-zero the 1971 and 1981 censuses, corresponding to three and one year after the Belice and the Irpinia-Basilicata earthquakes, respectively. The computed values plotted in figure 8 represent the difference between population growth rates at time-zero and at the year 2011 (i.e., last census collected data). The maps are therefore snapshots of the demographic growth over a time span of 40 (Belice, Figure 8.b) and 30 (Irpinia-Basilicata, Figure 8.d) years for the two disasters, respectively. Heavy damaged areas are generally in red to yellow colors, indicating negative population growth (Figg. 8.b and 8.d). However, we remark that for the Irpinia-Basilicata disaster the municipality of Lioni, classified with $I=10$, is the only one that in 30 years recorded a population growth, a low ageing index and a high child-woman ratio (see below). These indexes highlight that possibly in Lioni the process of recovery from the disaster might have been successful, requiring further investigation for this area.
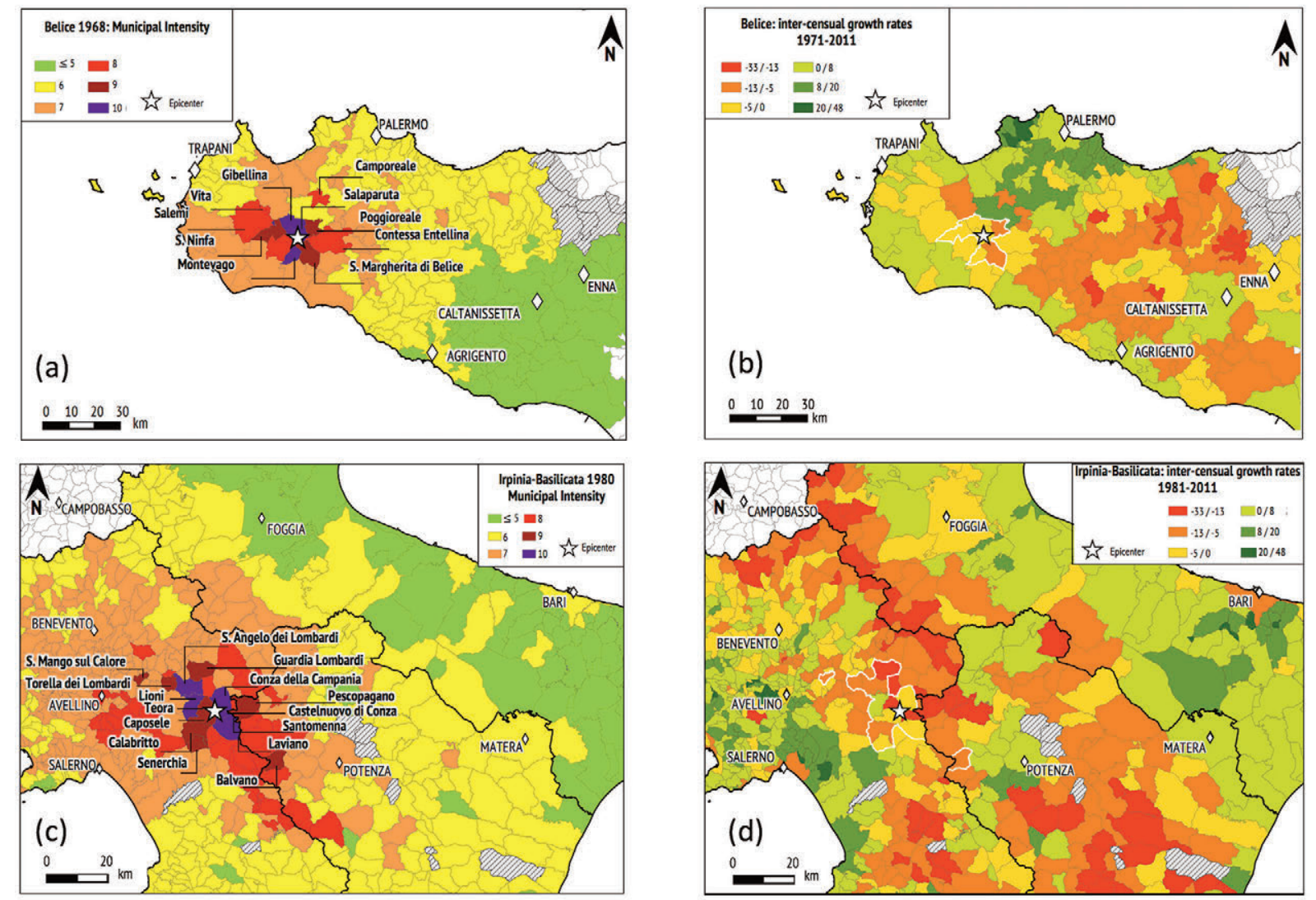

Figure 8. Post seismic disaster observations: Inter censual growth rates maps (b and d) compared to the municipal intensity maps (a and c) for the Belice (upper panel) within the time span 1971-2011, and the Irpinia-Basilicata (lower panel) within the time span 1981-2011. White diamonds are provincial capital cities. Hatched areas are municipalities excluded from the analysis (see text). (a), (c): Municipal macroseismic Intensities map representations; villages classified as $\mathrm{I}=8, \mathrm{I}=9$ and $\mathrm{I}=10$, for the Belice, and $\mathrm{I}=9$ and $\mathrm{I}=10$, for the Irpinia-Basilicata, are labelled. (b), (d): growth rates difference over time; villages classified as $\mathrm{I}=9$ and $\mathrm{I}=10$, for the Belice area (b), for the Irpinia-Basilicata area (d), are white contoured.

In summary, it seems clear that municipalities most affected by the two seismic events were those that previously already underwent depopulation and probably demographic distress [Golini, 2019; Golini, Mussino, and Savioli, 2000]. It is therefore conceivable that abandoned or at least little (or no) maintenance on buildings may have enhanced the impact of the earthquakes. In other words, demographic distress could contribute to raise buildings 


\section{Maddalena De Lucia et al.}

vulnerability. This may have important consequences on disaster prevention. We suggest that, at least for the areas affected by the 1980 Irpinia earthquake, demographic distress may counterbalance or even deny the expectation for which damaging past earthquakes should trigger reconstruction, reinforce building response to shaking and prompt changes in the individual risk perception [Valensise et al., 2017]. This hypothesis can probably be tested on the basis of census data on buildings conditions.

Other than the above considerations, there are not further clear effects of the analyzed seismic events on the demographic dynamics. The municipalities most affected by the earthquake continued to have generally lower values of population growth rates. The gap in the growth rates with other municipalities has often narrowed, but at the end of the period considered these municipalities have seen their demographic weight reduced (see section 4.1).

\subsection{Heterogeneities in population structures by age}

The data on the demographic structure of the populations allow to add further elements to support the considerations proposed so far. The data on residents broken down by age class and gender are available in digital form only from the 1971 census, thus in this section we refer to the period 1971-2011.

The ageing index allows us to examine the ageing process through the relationship between the elderly ( 65 years and over) and the young (under 15 years) people. The municipalities most affected by the Belice earthquake ( $\mathrm{I}=8$ and I $\geqslant 9$ ) had a higher level of ageing in 1971 than the other Sicilian municipalities (Figure 9.a), except for those with $\mathrm{I}=7$, which had values similar to the municipalities with I $\geqslant 9$. Over time, the ageing process has continued, so much that in the entire region the number of elderly people has risen from 40 to 126 on average per 100 young people. In other words, the weight of people aged 65 and over increased from $11 \%$ to $19 \%$ of the entire population in the period 1971-2011. The differential to the detriment of municipalities hit hard or intermediate by the earthquake has been maintained, widening in the case of localities with a I $\geqslant 9$. The level of ageing of the municipalities classified in I=7 class appears to be higher than the municipalities little or not at all affected by the earthquake.
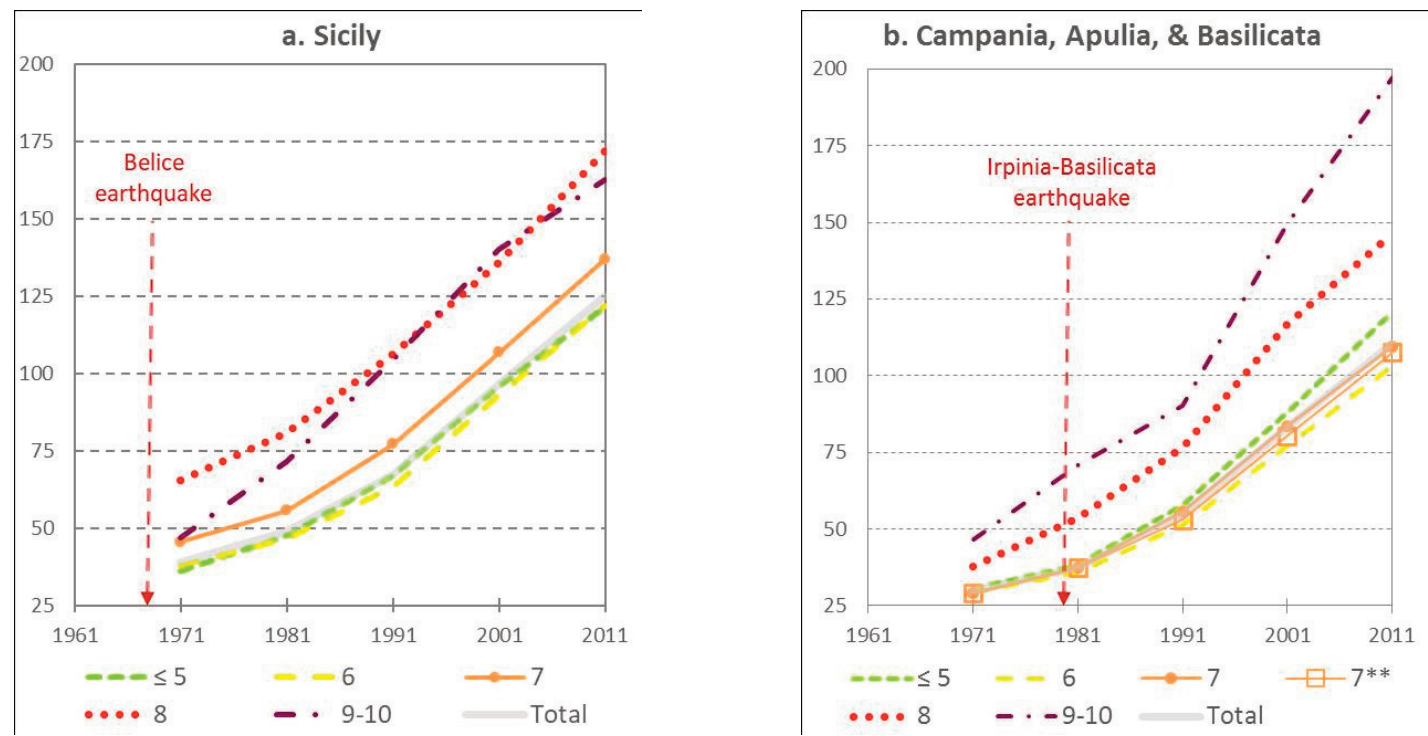

Figure 9. Ageing index (number of persons aged 65 and over per 100 persons aged 0-14), according to the macroseismic intensity classes used in this study. 9-10 class includes both I=9 and I=10 municipalities. Colour code is the same than in figure 6. Municipalities of Sicily (a) and of Campania, Apulia, and Basilicata together (b), for the time period 1971-2011. In both panels only the municipalities selected for the analysis are considered (see note in Table 5). In b. the line $7^{* * *}$ identifies the I=7 class without the municipality of Naples. Source: our elaboration on Istat census data from the information system "Atlante Statistico dei Comuni Italiani”. 
Fertility decrease is a phenomenon widespread all over the selected area, nevertheless the municipalities classified I=7 present the same or higher values of the child-woman ratio compared to the higher classes of I (Figure 10.a). This could be the reason for a less marked ageing and a slight growth of the population. The positive correlation between depopulation and ageing processes is a known process, documented by some recent empirical studies concerning the Italian context [Reynaud and Miccoli, 2018].

Even the municipalities most affected by the Irpinia-Basilicata earthquake were more advanced in the ageing process already before 1980 and remained in a position of greater aging than the other municipalities in the following decades, with a particularly strong progression for all municipalities classified on I $\geqslant 9$ class (Figure 9.b). In this case, the large group of municipalities with $\mathrm{I}=7$ was and remains at an ageing level equal to or below the average of the selected municipalities of the three regions as a whole (without significant differences when the municipality of Naples is excluded from the analysis). The child-woman ratio is also more or less equal to the overall average, above the values recorded by the municipalities most affected by the earthquake, except for 1991 (Figure 10.b). Indeed, for this latter date, the child/women ratio for the classes $I=8$ and $I \geqslant 9$ is similar or larger than the lower classes and than the overall average as well. This could result from a smaller decrease in the propensity to fertility in the years following the disaster in the most affected areas. This evolution could be substantially in line with what has been observed in other cases in which a greater propensity to fertility was recorded immediately after the earthquake [Frankenberg et al., 2014; Finlay, 2009; Nobles et al., 2016].
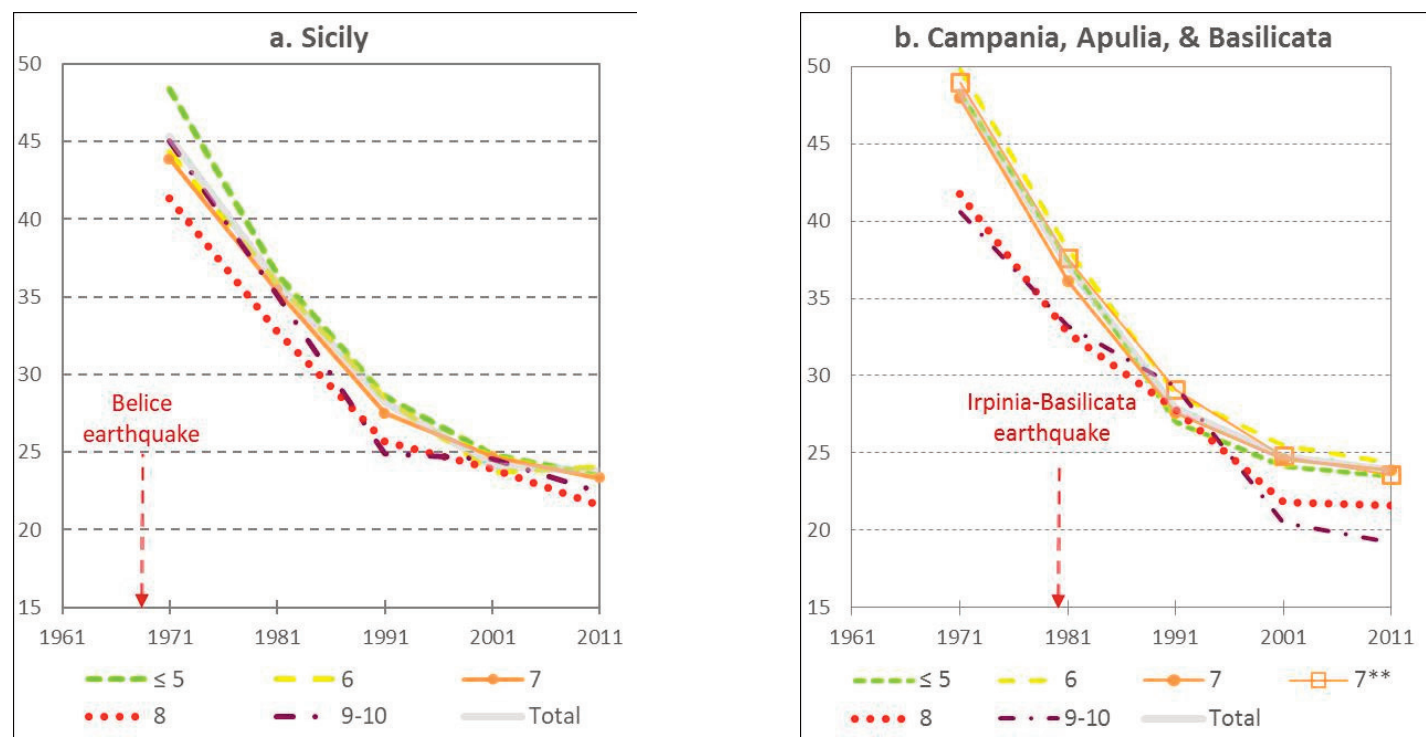

Figure 10. Child-Woman Ratio (number of children under age 5 per 100 women aged 15-44), according to the macroseismic intensity classes used in this study. Color code is the same than in figure 6. 9-10 class includes both $\mathrm{I}=9$ and $\mathrm{I}=10$ municipalities. Municipalities of Sicily (a) and of Campania, Apulia, and Basilicata together (b), for the time period 1971-2011. In both panels only the municipalities selected for the analysis are considered (see note in Table 5). In b. the line $7 * *$ identifies the I=7 class without the municipality of Naples. Source: our elaboration on Istat census data from the information system "Atlante Statistico dei Comuni Italiani”.

Anyway, it is clear that the municipalities that have suffered the greatest damage are those of depopulation before and after the event, with a faster ageing process probably due to the combination of reducing births and negative migration balances. The framework is therefore a vicious circle linking depopulation, demographic ageing, and greater fragility of the territories. This phenomenon has been causing concern among population scholars and regional economists for some time [Sonnino, 1979], so much that European and national institutions have promoted many actions to counteract the dynamics of depopulation, such as the National Strategy for the Internal Areas, in Italy. 


\section{Maddalena De Lucia et al.}

\subsection{Processes of spatial concentration}

One of the possible effects of seismic disasters, even in the long term, concerns the processes of redistribution of the resident population. An indirect way of detecting the occurrence and measuring this effect is to quantify the diachronic evolution of spatial concentration of the resident population in the municipalities grouped according to the macroseismic intensity.

Figure 11 displays the Gini index in the time period 1951-2011, illustrating the evolution of the spatial concentration of the population in the whole considered regions. The general trend observed here, in line with the whole country, indicates the progressive spatial concentration of the regional population, with a generalized increase of the Gini index during 1951-2011 (from 51.0 to 62.7 for Sicily and from 65.3 to 73.1 for Campania, Apulia, and Basilicata).

In this framework, however, there are heterogeneities in both level and dynamics of spatial concentration of the population. In Sicily, concentration levels higher than the regional average are recorded by municipalities in I=6

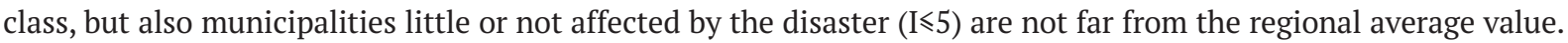
Both classes of municipality record intense growth of the Gini index, independently from the Belice earthquake occurrence. In the first case it passes from 61.4 in 1951 to 73.4 in 2011, while in the second it grows from 48.6 to 59.5 in the same period. So, where the earthquake has had the least impact, the population has tended to increase (Figure 7) and so has its level of territorial concentration, thus indicating processes of spatial thickening of settlement geographies. On the contrary, comparatively low levels of spatial concentration of the population are recorded by the municipalities with the highest macroseismic intensities. In particular, in the $I \geqslant 9$ municipalities, the index is less than 15.0 for the whole period here observed. The municipalities with macroseismic intensity I=7 record a trend of the Gini index similar to that of the municipalities in the lower classes, even though on a lower level: the index passes from 28.1 in 1951 to 36.2 in 2011. Differently from the above, the municipalities with $\mathrm{I=}=8$ show a substantially constant trend, thus indicating a very weak process of areal concentration of the population (from 37.6 in 1951 to 38.0 in 2011).

Also for Campania, Apulia, and Basilicata all the municipalities show a general tendency towards a progressive territorial concentration of the resident population. In particular, the municipalities belonging to the I=7 class mark levels of concentration higher than the regional average (index was 70.1 in 1951 and become 77.5 in 2011). On the other hand, the trend of the municipalities belonging to the lowest macroseismic intensity class is quite diversified. Indeed, the municipalities of the $I \leqslant 5$ class display a very weak increase, from 65.8 to 66.8 , indicating a very slow and soft process of spatial concentration of the resident population, while the class $\mathrm{I}=6$ started from a comparatively low initial level (35.1 in 1951), then shows a very intense growth from 1951 to 1961 and in the end slightly overcomes the regional average value (the index is 73.3 in 2011). The municipalities with the highest seismic intensities (I=8 and $\mathrm{I} \geqslant 9)$ are in an intermediate situation. In particular, even remaining at levels of territorial concentration well below the regional ones, the municipalities belonging to the $\mathrm{I}=8$ class show a progressive increase in spatial density (Gini index passes from 42.3 in 1951 to 58.2 in 2011). This is also the case for the municipalities with the highest seismic intensity (I $\geqslant 9$ ), albeit at much lower levels and with lower net trends (Gini index growths from 21.3 to 27.8 in the observed period).

The results obtained should be read with some caution. This is because the municipalities belonging to the different categories of macroseismic intensity are often not spatially contiguous and therefore could not be read, strictly speaking, as a spatially homogeneous territorial system on which the spatial concentration of the population is normally measured.

The data on spatial concentration of population show some regularity with respect to what emerged in terms of population dynamics but also some singularities. In Sicily, the municipalities that had stronger macroseismic effects from the Belice earthquake have comparatively low levels of population concentration for the whole period observed here. This again indicates their 'marginality' with respect to the processes of redistribution of the regional population. The case of Campania, Apulia, and Basilicata is different. Also in this case, in fact, the spatial concentration levels of the population of the municipalities with the highest macroseismic classes are comparatively reduced compared to the ones of the other municipalities. Nevertheless, their growth dynamics have been of a certain importance.

From these data, no clear effects of the disasters on the territorial concentration of the resident population are detectable. However we remark that these aspects require further investigation, considering also geomorphologic variables not analyzed here. 

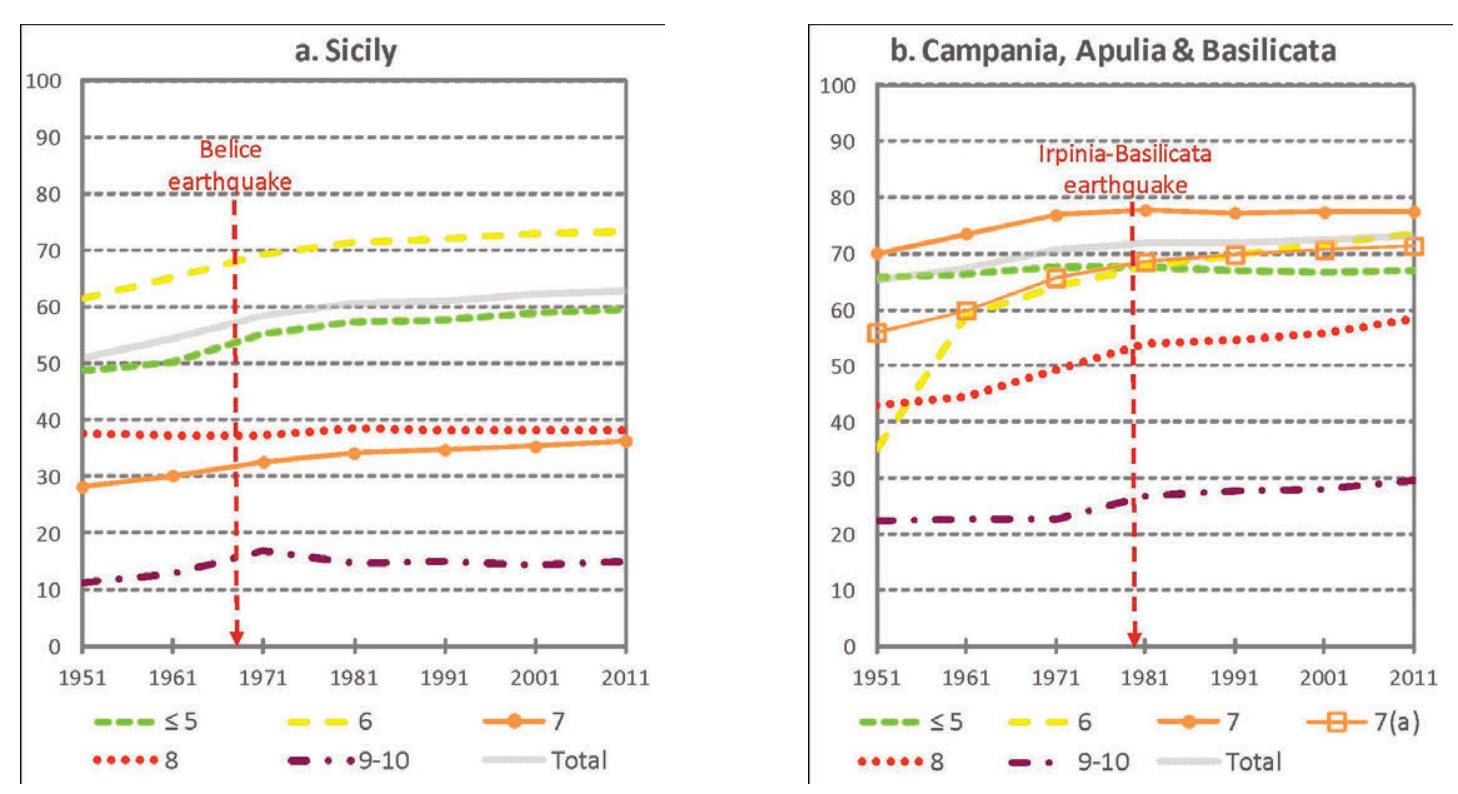

Figure 11. Gini index, according to the macroseismic intensity classes used in this study. Colour code is the same than in figure 6. 9-10 class includes both $\mathrm{I}=9$ and $\mathrm{I}=10$ municipalities. Municipalities of Sicily (a) and of Campania, Apulia and Basilicata together (b), 1951-2011. In this analysis all the municipalities of the four regions are considered. In b. the line 7(a) identifies the I=7 class without the municipality of Naples. Source: our elaboration on Istat census data from the information system "ottomila census” (www.ottomilacensus.it).

\section{Conclusions}

We carried out a pilot study to investigate the impact on local communities of the 1968 Belice and 1980 Irpinia-Basilicata earthquakes from a demographic perspective. The present study is the first detailed and quantitative analysis that associates the demographic evolution of areas hit by seismic disasters to the macroseismic intensity in order to explore the post-disaster picture over a long time interval.

We combine seismic parameters describing the effect of disasters to those depicting dynamics and structure of the populations. We analyzed changes in demographic parameters in the decades across the occurrence of the two seismic disasters. More specifically, for each one of the two events, we computed average annual growth rates, ageing index, child-woman ratio, and Gini index of spatial concentration from the demographic data censuses in the 1951-2011 time frame, by grouping municipalities according to distinct macroseismic intensity classes.

The analysis stands on the definition of the study area, considered as the domain where that specific earthquake did have significant effects that could affect the anthropic environment.

For both seismic disasters, residents in 2011 in the municipalities with higher classes of macroseismic intensity are less than in 1951, except for Campania, where municipalities with $\mathrm{I}=8$ show a slight increase in the absolute number of inhabitants. Lower intensity areas have an even larger increment in the same time span, with the exception of $I \leqslant 5$ municipalities in Sicily (excluding the four eastern provinces), where the resident population slightly decreases.

Surprisingly, in the intercensual decade after the event, for both study areas the municipalities with $I \geqslant 9$ display a lower gradient in the decrease of population than what observed in the previous decade. Municipalities with I=8 in the Belice area show a similar trend, whereas those in the same class for the 1980 earthquake exhibit a population increase, even though lower than the previous decade.

In both areas, in the decade after the event the population has a general increase in all $I \leqslant 7$ municipalities (excluding Naples).

An exception is the I $\leqslant 5$ class in Sicily, where the decrease observed in the previous decades stops. 


\section{Maddalena De Lucia et al.}

For the two study areas, in the time before the relevant earthquake, population growth rates in the most affected municipalities have a strong negative gap compared to those less or not at all affected by the earthquakes. The gap decreases across and after the earthquakes, still remaining negative.

Overall, for the whole 1971-2011 period and in both the considered areas, the population show an increasing level of ageing. The municipalities most affected by the disasters display a higher ageing index compared to the lowest intensities classes. In the same decades the child-woman ratio shows a general decrease, which possibly evidences reducing birth, in turn contributing to a faster ageing process. For the 1980 earthquake, the child/women ratio for the classes I=8 and I $\geqslant 9$ display a less steep decrease in 1991 with respect to their general trend. This could result from a smaller reduction in the propensity to fertility following the earthquake in the most affected areas, as observed for other disasters [Frankenberg et al., 2014; Finlay, 2009; Nobles et al., 2016].

The general evolution of the distribution of resident population is in line with the whole country, and describes a progressive spatial concentration during 1951-2011. The observed trends do not show substantial changes before and after the occurrence of the two studied earthquakes, but highlight the differences among individual intensity classes. For both seismic disasters, municipalities with stronger macroseismic effects have in general comparatively low levels of population concentration, before and after the earthquakes.

In general, the areas classified with macroseismic intensities higher than 7 show unfavorable demographic dynamics (i.e., depopulation and high ageing index), low child-woman ratio, low spatial concentration, already before the disasters stroke. All these observations depict a general framework of demographic distress of the areas most affected by the seismic events. This might have enhanced the impact of earthquakes: depopulation processes might be associated in fact with an increase in building vulnerability. It is indeed conceivable that the demographic dynamics observed in these areas could result in little or even no maintenance of buildings. In some cases (i.e., Belice) land abandoning was also reinforced by a general strategy endorsed by the government within the emergency phase [Guidoboni and Valensise, 2011]. Thus demographic distress appears to be a factor negatively affecting the seismic vulnerability. It may counterbalance the expectation for which damaging past earthquakes should trigger proper reconstruction and reduce building vulnerability, fostering changes in the individual risk perception.

From a different perspective, depopulation of more seismic areas could also have the positive effect to move population in safer areas, with a gain in terms of security and even from an economic point of view.

Demographic data describe the dynamics of the population in an area, even though their interpretation is not straightforward, for the multiplicity and the complexity of the contributing factors. Natural disasters are among these. Our analysis highlights that demographic evolution across seismic disasters follow not easily predictable dynamics. However, the distinct trends among the different intensity classes within each area - and between the two areas themselves -resulting from our study represent relevant issues for debate and further deepening. Additional information of the internal variability of the demographic groups and more detailed data, also on the role of the components of the demographic dynamics, could help to better delineate the whole picture.

Acknowledgements. We are grateful to Mario Locati (INGV) for his kind and effective support. Fruitful suggestions by anonymous reviewers helped to improve this manuscript.

The opinions expressed here are those of the authors and do not necessary reflect the ones of their Institutions.

\section{References}

Alessio, G., E. Esposito, A. Gorini, S. Porfido (1995). Detailed study of the Potentino seismic zone in the Southern Apennines, Italy. Tectonophysics, 250 (1-3), 113-134.

Barreca, G., V. Bruno, C. Cocorullo, F. Cultrera, L. Ferranti, F. Guglielmino, L. Guzzetta, M. Mattia, C. Monaco and F. Pepe (2014). Geodetic and geological evidence of active tectonics in south-western Sicily (Italy). J. Geodyn., 82, 138-149. http://dx.doi.org/10.1016/j.jog.2014.03.004

Beale, C. V., (1964). Rural depopulation in the United States: some demographic consequences of agricultural adjustments. Demography, 1(1), 264-272.

Bottai M. and F. Benassi, (2016). Migrations, daily mobility, local identity, housing projects in Italy: A biographical 
approach. Portuguese Journal of Social Sciences, 15, 1, 47-68.

Caldo C. (1975) Sottosviluppo e terremoto. La valle del Belice. Manfredi, Palermo, 135.

Doocy, S., A. Daniels, C. Packer, A. Dick and T. D. Kirsch (2013). The Human Impact of Earthquakes: a Historical Review of Events 1980-2009 and Systematic Literature Review, PLOS Currents Disasters, 5. doi:10.1371/currents.dis.67bd14fe457f1db0b5433a8ee20fb833

ESPON (2017). Shrinking rural regions in Europe: Towards smart and innovative approaches to regional development challenges in depopulating rural regions. Espon Policy in brief, Luxemburg (https://www.espon.eu/sites/default/files/attachments/ESPON\%20Policy\%20Brief\%20on\%20Shrinking\%20Ru ral\%20Regions.pdf)

Finlay, J. E. (2009). Fertility Response to Natural Disasters. The Case of Three High Mortality Earthquakes. Policy Research Working Paper No 4338. Washington, DC: World Bank.

Frankenberg, E., M. Laurito and D. Thomas (2014). The demography of disasters. in International Encyclopedia of the Social and Behavioural Sciences. 2nd Edition. Amsterdam, 1-22.

Freire, S. and C. Aubrecht (2012). Integrating population dynamics into mapping human exposure to seismic hazard. Nat. Hazards Earth Syst., 12, 3533-3543.

Gizzi, F. T., M. R. Potenza and C. Zotta (2012). 23 november 1980 Irpinia-Basilicata earthquake (Southern Italy): toward a full knowledge of the seismic effects. Bull Earthquake Eng., 10, 1109-1131.

Golini, A. (2019). Italiani poca gente. Il Paese ai tempi del malessere demografico. Luiss University Press.

Golini, A., A. Mussino and M. Savioli (2000). Il malessere demografico in Italia. Una ricerca sui comuni italiani. Il Mulino, Bologna.

Guidoboni E. and G. Valensise (2011). Il peso economico e sociale dei disastri sismici in Italia negli ultimi 150 anni (1861-2011), Centro EEDIS-INGV, Bononia University Press, Bologna, 552.

ISIDe working group (2016) version 1.0, DOI: 10.13127/ISIDe.

Lasanta, T., J. Arnáez, N. Pascual, P. Ruiz-Flaño, M. P. Errea and N. Lana-Renault (2017). Space-timeprocess and drivers of land abandonment in Europe. Catena, 149, 810-823.

La Stampa, (newspaper) 1968, January, $23^{\text {th }}$ edition.

Livi Bacci, M. (1981). Introduzione alla demografia. Loescher Editore, Torino.

Locati, M., R. Camassi, A. Rovida, E. Ercolani, F. Bernardini, V. Castelli, C. H. Caracciolo, A. Tertulliani, A. Rossi, R. Azzaro, S. D’Amico, S. Conte and E. Rocchetti (2016). DBMI15, the 2015 version of the Italian Macroseismic Database. Istituto Nazionale di Geofisica e Vulcanologia. doi: http://doi.org/10.6092/INGV.IT-DBMI15.

McKibben, J. N., and K. A. Faust (2004). Population Distribution-Classification of Residence. In: The Methods and Materials of Demography, J.S. Siegel and D.A. Swanson (eds). Elsevier Academic Press, San Diego, California, 105-124.

Meroni, F., T. Squarcina, V. Pessina, M. Locati, M. Modica and R. Zoboli (2017). A Damage Scenario for the 2012 Northern Italy Earthquakes and Estimation of the Economic Losses to Residential Buildings, Int J Disaster Risk Sci, 8, 326-341, doi:10.1007/s13753-017-0142-9.

Nobles, J, E. Frankenberg, and T. Duncan (2015). The effects of mortality on fertility: population dynamics after a natural disaster. Demography, 52, 15-38. doi: 10.1007/s13524-014-0362-1.

Pantosti, D. and G. Valensise (1993) Source geometry and long-term behavior of the 1980, Irpinia earthquake fault based on field geologic observations, Annali di Geofisica 36(1), 41-49.

Philip, G. M., and D. F. Watson (1982). A Precise Method for Determining Contoured Surfaces. Australian Petroleum Exploration Association Journal, 22, 205-212.

Pino, N.A., D. Giardini e E. Boschi (2000). The 1908 December 28 Messina Straits (southern Italy) earthquake: waveform modeling of regional seismograms, J. Geophys. Res., 105, 25473-25492, doi:10.1029/2000JB900259.

Poljanšek, K., M. Marin Ferrer, T. De Groeve and I. Clark (eds.) (2017). Science for disaster risk management 2017: knowing better and losing less. EUR 28034 EN, Publications Office of the European Union, Luxembourg, ISBN 978-92-79-60679-3, doi:10.2788/842809, JRC102482.

Reynaud, C., and S. Miccoli (2018). Depopulation and the Aging Population: The Relationship in Italian Municipalities. Sustainability, 10(4), 1004, https://doi.org/10.3390/su10041004.

Rossi, L., B. Holtschoppen and C. Butenweg (2019a). Official data on the economic consequences of the 2012 EmiliaRomagna earthquake: a first analysis of database SFINGE. Bull. Earthquake Eng. doi: 10.1007/s10518-019-00655-8. 


\section{Maddalena De Lucia et al.}

Rossi, A., A. Tertulliani, R. Azzaro, L. Graziani, A. Rovida, A. Maramai, V. Pessina, S. Hailemikael, G. Buffarini, F. Bernardini, R. Camassi, S. Del Mese, E. Ercolani, A. Fodarella, M. Locati, G. Martini, A. Paciello, S. Paolini, L. Arcoraci, C. Castellano, V. Verrubbi and M. Stucchi (2019b). The 2016-2017 earthquake sequence in Central Italy: macroseismic survey and damage scenario through the EMS-98 intensity assessment. Bull Earthq Eng. https://doi.org/10.1007/s10518-019-00556

Rovida, A., M. Locati, R. Camassi, B. Lolli and P. Gasperini (eds), (2016). CPTI15, the 2015 version of the Parametric Catalogue of Italian Earthquakes. Istituto Nazionale di Geofisica e Vulcanologia. doi: http://doi.org/10.6092/INGV.IT-CPTI15

Rovida A., M. Locati, A. Antonucci, R. Camassi (eds), (2019). Archivio Storico Macrosismico Italiano (ASMI). Istituto Nazionale di Geofisica e Vulcanologia (INGV). https://doi.org/10.13127/asmi

Scibilia, F. (2016). The reconstruction of Gibellina after the 1968 Belice earthquake. In International Planning History Society Proceedings Carola Hein (ed.), 17th IPHS Conference, History-Urbanism-Resilience, TU Delft 17-21 July 2016, V.02 p.313, TU Delft Open.

Sieberg, A. (1930). Geologie der Erdbeben, Handbuch der Geophysik, 2(4), 552-555.

Sonnino, E. (1979). Ricerche sullo spopolamento in Italia: 1871-1971. L'evoluzione del fenomeno e alcuni suoi riflessi sulla recente dinamica demografica. Istituto di Demografia, Università di Roma La Sapienza, Roma.

Twigg, J. (2001). Corporate Social Responsibility and Disaster Reduction: A global overview. London. Aon Benfield UCL Hazard Centre.

UNISDR (United Nations International Strategy for Disaster Reduction), 2009. Terminology on disaster risk reduction. United Nations.

Valensise, G., G. Tarabusi, E. Guidoboni and G. Ferrari (2017). The forgotten vulnerability: a geology- and historybased approach for ranking the seismic risk of earthquake-prone communities of the Italian Apennines. International Journal of Disaster Risk reduction, 25, 289-300.

Watson, D. F., and G. M. Philip (1985). A Refinement of Inverse Distance Weighted Interpolation. Geoprocessing, 2, 315-327. 